
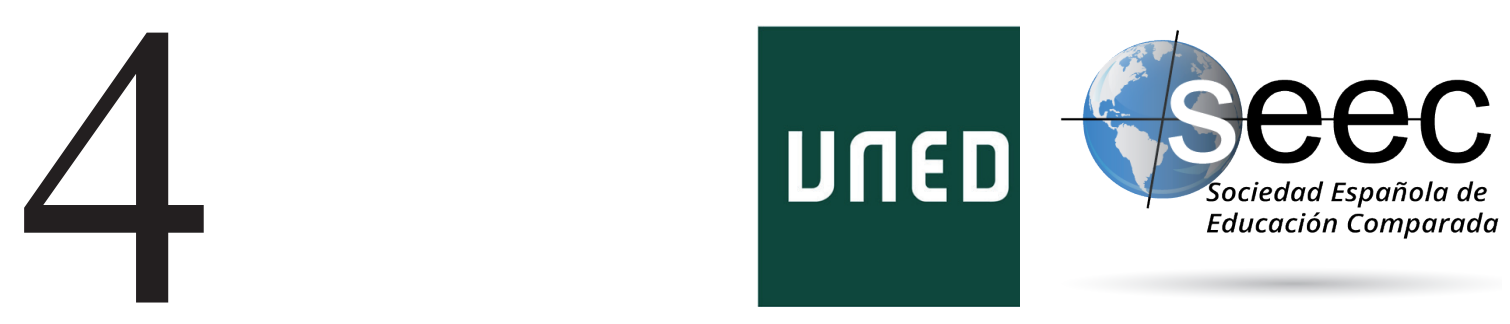

\title{
Evangelización e instrucción pública en el orden colonial español*
}

\author{
Evangelization and public instruction \\ in the Spanish colonial order
}

\section{Alberto Martínez Boom**}

DOI: $10.5944 /$ reec.31.2018.21916

\section{Recibido: 23 de abril de 2018 Aceptado: 21 de junio de 2018}

\footnotetext{
* Agradecimientos: quiero agradecer a Estela Restrepo Zea la lectura realizada de este documento, sus aportes conceptuales, las precisiones historiográficas y su corrección detallada; también a Jhon Henry Orozco Tabares su trabajo con la escritura y con la lectura de las fuentes documentales. Este artículo es resultado del proyecto de investigaciones «Escuela pública y saber pedagógico en Colombia, finales del siglo XVIII y principios del XIX» que contó con el apoyo financiero del Centro de Investigaciones de la Universidad Pedagógica Nacional (Código DCE-004-7).

**Alberto Martínez Boom: Doctor en Filosofía y Ciencias de la Educación por la UNED (España). Profesor titular Universidad Pedagógica Nacional (Bogotá) en el Doctorado Interinstitucional en Educación de las universidades del Valle, Distrital y Pedagógica Nacional. Investigador Emérito de Colciencias. Miembro fundador y activo del Grupo de Historia de la Práctica Pedagógica. Miembro de número de la Academia Colombiana de Pedagogía. Entre sus libros se destacan: Escuela, maestro y métodos en Colombia 1750-1820 (1986), Maestro, escuela y vida cotidiana en Santafé colonial (1999), Currículo y modernización. Cuatro décadas de educación en Colombia (2003), De la escuela expansiva a la escuela competitiva. Dos modos de modernización en América Latina (2004), Verdades y mentiras sobre la escuela (2012), Epistemología de la pedagogía (2016). Datos de contacto: Web-site: www.albertomartinezboom.com, e-mail: almarboom@gmail.com
} 


\title{
Resumen
}

La ocupación de los territorios conquistados por el imperio español alcanzó mediante las prácticas de doctrina y evangelización la sustitución de unos elementos culturales por otros, esta implantación de nuevas formas de vida supuso además de la fuerza el despliegue sistemático de labores educativas. El tiempo de la Colonia con sus instituciones políticas, sociales y religiosas fue también el tiempo de la encomienda, la manumisión, el regalismo borbónico y la gestación de algunas de las condiciones que hicieron posible la emergencia de la escuela pública en el Nuevo Reino de Granada. Rastrear este acontecimiento exige detenerse en la función del plan de escuela como documento privilegiado en la distinción analítica entre escuela y otros modos educativos.

Palabras clave: Doctrina; evangelización; encomienda; plan de escuela; catecismos; escuela pública

\begin{abstract}
The occupation of the territories conquered by the Spanish empire was carried out through practices of doctrine and evangelization for the substitution of cultural elements by others, this implementation of new forms of life also meant the systematic deployment of educational labors. The time of the Colony with its political, social and religious institutions was also the time of the encomienda, the manumission, the Bourbon regalism and the gestation of some of the conditions that made possible the emergence of public school in the New Kingdom of Granada. Tracing this event demands to stop at the function of the school plan as a privileged document in the analytical distinction between school and other educational modes.
\end{abstract}

Key Words: Doctrine; evangelization; encomienda; school plan; catechisms; public school 


\section{Introducción}

La descripción del orden colonial español en Hispanoamérica ha sido narrada desde enfoques metodológicos diversos. Los historiadores asumen posiciones estratégicas al momento de privilegiar un archivo o de optar por un punto de vista; de esta manera la historiografía ha propuesto paisajes generales, análisis casuísticos, caracterizaciones institucionales, entre otras. El resultado ha sido un conjunto importante de trabajos muchos de ellos en favor del imperio español y de su articulación a los distintos niveles administrativos de la América colonial. Esta experiencia historiográfica conecta -en líneas generales- lo histórico con lo jurídico y lo institucional (Pietschmann, 2001, p. 669) bajo el pretexto de reconstruir lo que creen fue la realidad cotidiana en los territorios de ultramar. Se destacan así los trabajos de Enrique Ruiz Guiñazú (1916), Rafael Altamira (1924), Guillermo Lohmann Villena (1947), Juan Manzano (1950), José Miranda González (1952), Charles Gibson (1964), José María Ots Capdequí (1965), Lilian Estelle Fisher (1966), Silvio Zavala (1972), John Lynch (1976), Magnus Mörner (1979), Richard Konetzke (1982), Jorge Ignacio Rubio Mañe (1983), Alfonso García Gallo (1987) y Mario Góngora (1998), por mencionar algunos de los más conocidos.

En relación con la Escuela de los Anales y otras propuestas de la historiografía anglosajona circulan trabajos dirigidos a reorientar la perspectiva imperial hacia problemas socioeconómicos regionales, específicamente por el empleo de archivos locales. Abarca este espectro los estudios historiográficos de Juan Friede (1963), Marcelo Carmagnani (1963), Sergio Villalobos (1965), Jaime Jaramillo Uribe (1968), Germán Colmenares (1975), Federico Brito (1978), Margarita González (1979), Pilar Gonzalbo (1985), Dorothy Tanck (1999), Anne Staples (2005), Estela Restrepo Zea (2011), Bohumil Badura (2013), entre otros. Las variantes regionales y el recurso de otras fuentes documentales introducen complementos y tensiones en el significado político de la dominación española.

El periodo de dominación española en América Latina recoge dos momentos: la conquista como una experiencia excesivamente violenta basada en relaciones de sometimiento y sumisión casi absolutas y las prácticas de ordenamiento colonial las cuales abarcaron procesos de institucionalización precarios, ambivalentes y dudosos explicados en parte porque los reinos castellanos de ultramar no fueron asumidos como colonia española, pero también porque existía un constante elemento de desconfianza que dificultaba gobernar con mayor criterio y certeza.

\section{Población y territorio}

La organización de los territorios americanos y de la población indígena se inició a partir de la dádiva recibida por los Reyes Católicos de parte del papado a través de la bula InterCaetera I de 5 de mayo de 1493 por medio de la cual Alejandro VI le otorgó a la Corona el poder y dominio sobre los territorios descubiertos y sobre los pobladores americanos con la condición de cristianizarlos o, en otras palabras, con el pretexto de expandir la religión y la Fe católica:

Por la autoridad del Omnipotente Dios [...] y del Vicariato de Jesucristo que ejercemos en las tierras, con todos los señoríos de las ciudades, cercas, lugares, villas [...] y todas sus pertenencias, por el temor de las presentes, las damos, concedemos y asignamos perpetuamente a vos y a los Reyes de Castilla y de León, vuestros herederos y sucesores. Y hacemos, constituimos [...] absoluto poder, autoridad y jurisdicción (Solorzano, 1776, p. 14). 
A partir de entonces la conquista de los inmensos territorios trasatlánticos fue breve en el tiempo y compleja en su ejecución pese a la participación de empresas particulares en los costos demandados por la empresa. Para poner ejemplo, puede mencionarse la conquista de México y Perú en las que intervinieron un número minúsculo de españoles: la expedición de Hernán Cortes contó con 415 hombres y la de Francisco Pizarro en su avance hasta Cajamarca alrededor de 170 . El ritual de la conquista, dispuesto desde sus inicios en las Capitulaciones, tuvo, desde 1514 aproximadamente, la formalización del «requerimiento» redactado por Juan López de Palacios Rubios, jurista de la corte de Fernando el Católico, el cual debía leerse a los indios del Nuevo Mundo.

En él comenzaba por explicar sumariamente la doctrina cristina, a fin de que los infieles supieran quién era Cristo, quién el Papa, y qué derechos tenían los cristianos para exigirles la sujeción a su poder. El último párrafo revela el sentido coactivo de esta demanda: cuando ya se ha dicho a los indios que todos los hombres son prójimos y descienden de Adán, se les pide que reconozcan a la Iglesia y al Papa, y al Rey y a la Reina como superiores de estas tierras por donación papal. Si quieren someterse, se les recibirá con todo amor y caridad, se les dejará sus mujeres, hijos y haciendas libres, y no se les compelerá a que se tornen cristianos, salvo si informados de la verdad desean convertirse, y el rey les hará muchas mercedes; si se niegan a obedecer, el capitán, con la ayuda de Dios, les hará guerra, y tomará sus personas y las de sus mujeres e hijos, y los hará esclavos y como tales los venderá (Zavala, 1972, pp. 28-29).

Convertir y ganar para la religión y reducirlos para extraer de aquellos débiles pobladores la mayor cantidad posible de beneficios fue a la larga el objetivo nodal de la conquista. El cronista Gómara testimonia estos motivos usando las palabras de Hernán Cortés: «la causa principal a que venimos a estas partes es por ensalzar y predicar la fé de Cristo, aunque justamente con ella se nos sigue la honra y provecho, que pocas veces caben en un mismo saco» (Zavala, 1972, p. 25). Hubo, por supuesto, otras valoraciones del proceso; el franciscano André Thevet no puede menos que lamentar la suerte de aquellas «pobres gentes» diezmadas, reducidas a esclavitud e incitadas al suicidio por los efectos de una barbarie «inaudita» y una codicia eminentemente condenable (Daviols, 2001, p. 491).

La organización eclesiástica en el Nuevo Mundo formalizó el entendimiento entre Papado y Corona. En 1508 el Papa Julio II mediante bula Universalis Eclesiae le confirió al Estado Español la facultad de presentar candidatos a la Santa Sede para la provisión de todos los arzobispados, obispados, dignidades y beneficios eclesiásticos americanos.

Esta delegación de potestad recibió el nombre de patronato. Su ejercicio se encomendó en América a los virreyes y audiencias. En virtud de ello el poder civil intervenía en casi todos los asuntos del poder eclesiástico: nombramiento de párrocos y doctrineros, distribución de 10 diezmos y pago de estipendios en el ceremonial de las catedrales, e incluso el recurso de fuerza para hacer que las sentencias eclesiásticas pudieran tratarse en tribunales laicos, lo que fue causa de distintos conflictos. La práctica del patronato generó múltiples controversias entre autoridades civiles y eclesiásticas frente al proceso de evangelización; particularmente entre el clero regular y secular. Con esta legislación y posteriores provenientes del Papa a favor de los Reyes de España se estableció 
La práctica del patronato [que] fue llevando a los juristas hispanos a formular la teoría del vicariato regio, según la cual el rey desempeñaba las funciones de vicario o delegado pontificio para todo el complejo misional de la América Hispánica (Pacheco, 1964, p. 77).

Gracias a ella los poderes civiles obtuvieron los recursos jurídicos para cumplir con el ejercicio de la palabra y, en el caso de la evangelización y catequización, la autorización y las facultades para realizar la conversión de los naturales.

En 1511, la bula Romanus Pontifex permitió la creación de las primeras diócesis en el nuevo mundo, mientras las Leyes de Burgos de 1512 ordenaban la construcción de templos por doquier. (Gutiérrez, 1992, p. 274). La diócesis representaba la unidad territorial máxima desde el punto de vista religioso y la facultad para efectuar en las Indias concilios y sínodos diocesanos en los cuales se abordaban las vicisitudes de la evangelización. Solo hasta mediados del siglo XVI se dispuso la organización de las diócesis en arquidiócesis; en 1546 se eligieron las primeras de ellas en Santo Domingo ${ }^{1}, \mathrm{México}^{2}$ y Lima ${ }^{3}$. El arzobispado de Santafé 4 se constituyó el 22 de marzo de 1564 con tres obispados sufragáneos: Santa Marta, Cartagena y Popayán.

A partir de la segunda década del siglo XVII la Corona Española en cabeza de Felipe III asumió por Cédula Real los mandatos del Concilio de Trento y ordenó a la Iglesia de América su adopción, aunque en la práctica ya habían entrado en ejercicio. En virtud de los mandatos emanados de la célebre asamblea, la evangelización de los infieles se regiría por el catecismo tridentino cuya circulación fue promovida en el Nuevo Reino por los concilios Limenses celebrados en 1583 y 1587. Las normas salidas de Trento dieron nuevo rumbo a la evangelización por legitimar las lenguas nativas como instrumento de enseñanza y comunicación religiosa entre doctrineros y naturales.

El trabajo de adoctrinamiento fue desde entonces una práctica civilizatoria por considerar a los nativos futuros vasallos del rey. No obstante la común iconografía del indio se movía entre la inocencia y la animalidad (Daviols, 2001, p. 490). Los naturales seguían considerándose «pueblos niños», salvajes y bárbaros incapaces de acceder a la civilización, equiparados a rústicos y menores y, por tanto, necesitados de tutela.

No tienen ni ley ni fe ninguna, viven de acuerdo a la naturaleza, no conocen la inmortalidad del alma. No tienen entre ellos bienes propios, porque todo es común; no tienen límite de reinos ni de provincias; no tienen rey ni obedecen a nadie: cada uno es señor de sí mismo. No administran la justicia, la que no les es necesaria, porque no reina en ellos codicia (Vespucci, 1951).

Para la población indígena la llegada de los españoles fue un desastre rotundo; de proporciones inauditas porque a las prácticas de sometimiento se sumaron las epidemias, soldado invisible de la expansión ibérica, la cuales causaron estragos en la población de América por la falta de inmunidad. La mayor mortandad ocurrió en México central, Nueva Granada y Alto Perú. Como señala Alfred Cosby (1972, p. 37), las enfermedades

1 De esta arquidiócesis dependía San Juan, Santiago, Jamaica, Coro, Santa Marta, Cartagena y Trujillo.

2 Comprendía Puebla-Tlaxcala, Antequera de Oaxaca, Michoacán, Guatemala, Chiapas y Nueva Galicia.

3 De la que dependían Cuzco, Quito, Popayán, Panamá y Nicaragua.

$4 \quad$ La arquidiócesis de Santafé comprendía las ciudades de Santafé, Tunja, Vélez, Pamplona, San Cristóbal, Mérida, Tocaima, Ibagué, San Sebastián de Mariquita, Victoria, Santa María de los Remedios, La Palma, Trinidad de los Muzos, San Juan de los Llanos y San Vicente de los Paeces. En: AGI, Audiencia de Santafé, Legajo 1249, fol. 25. 
mortales del Viejo Mundo lo eran aún más en el Nuevo y los males relativamente benignos de Europa resultaron asesinos en América. En el siglo que siguió a la conquista, la viruela, el sarampión, la varicela, la tos ferina, la gripe, la difteria, la disentería amebiana y el tifus mataron un número asombroso de habitantes reduciendo hasta un $95 \%$ la población indígena en algunos territorios.

\section{A partir de 1492 y durante la primera mitad del siglo XVI la nación indígena fue víctima de enfermedades [...] En efecto, en 1496 se presentó en la Española una epidemia de gripe que acabó con una tercera parte de los indígenas. En 1518 llegó la viruela, que se propagó luego por el Caribe y poco tiempo después entró a México. De la Nueva España, territorio en el cual terminó con la mitad de los habitantes, pasó a Centroamérica y siete años después de su introducción a la América Hispánica hizo su arribo al virreinato del Perú (Restrepo, 1997, p. 63).}

Otros trabajos historiográficos exploran distintas causas sobre el descenso de la población indígena en la primera centuria de la conquista, entre ellas las acciones bélicas de los conquistadores cuando se topaban con resistencias; la dureza del trabajo en minas y obrajes a los que no estaban acostumbrados los naturales; la disolución de rutinas de la vida cultural, sexual y familiar por las prácticas de reducción. Las distintas agrupaciones tuvieron a menudo un carácter artificial por haber sido fundadas por huestes de conquistadores que no habían tomado en cuenta los diversos factores medioambientales. De ahí que en el siglo XVI muchas de ellas se convirtieran en poblaciones ambulantes trasladas dos o tres veces antes de encontrar un asentamiento definitivo ${ }^{5}$.

La disminución constante de los aborígenes dio oportunidad de ascenso social de otras poblaciones, en particular, negros y mestizos. La población negra comenzó en la Nueva Granada desde los primeros años de la conquista y a mediados del siglo XVI eran numerosos. Cartagena, principal puerto en Tierra Firme fue «asilo de viajeros y posada de comerciantes». Con motivo de las expediciones de reconocimiento realizadas en las Antillas, llegaban a la plaza empresas de guerra y de comercio, hombres de mar y gentes de trabajo que compartían el puerto con tratantes y esclavos (Restrepo, 1997, p. 69). En virtud de la súplica que hiciera el padre De Las Casas al emperador Carlos V para que cada colono pudiese traer a América dos pares de negros con el fin de contrarrestar la despoblación indígena que ya se había sentido en las Antillas, el puerto fue lugar de convivencia de españoles, esclavos y nativos.

$5 \quad$ El periodo de 1560 a 1579 fue de expansión y consolidación social en Hispanoamérica. Mörner nos dice que buena parte de la migración española llegó principalmente a Nueva España y Perú. Indica además que cerca del $42 \%$ de la población peninsular era andaluza y con un fuerte componente de migración femenina. Para un castellano la vida urbana era la única forma cristina de vida por eso la fundación de las ciudades implicó incorporar los trazados urbanísticos que se reiteraron en cada ciclo fundacional de pueblos. Se impuso así el trazo de cuadrícula con una plaza mayor en el centro del pueblo, en torno a la cual se erigía la iglesia principal, el ayuntamiento y las residencias principales. Esta disposición espacial resultó eficaz, entre otras cosas, porque permitió un crecimiento demográfico considerable, sin necesidad de realizar grandes cambios. Al mismo tiempo, la cuadrícula iba a reflejar fielmente los valores de una sociedad profundamente jerárquica. En el centro vivirían los vecinos principales, inicialmente casi todos encomenderos, a mayor distancia, los de categoría mediana, y en la periferia, las capas populares, por lo general de piel más oscura. Según el principio vigente de las dos repúblicas, de españoles y de indios, respectivamente, estos últimos deberían vivir en pueblos propios, trazados de la misma forma, pero sin otros pobladores extranjeros que el párroco o el misionero (Mörner, 2001, p. 424). Santa Cruz de Mompox (Bolívar) conservó incluso hasta el siglo XX la organización de sus calles reales: la calle del oro, la calle de la plata y la calle de bronce como expresión de una división estratificada del espacio físico y social. Posteriormente aparecieron las Reales Ordenanzas de población, en 1573, cuando las principales ciudades Hispanoaméricas ya habían sido fundadas. 
En virtud de los acuerdos entre la monarquía y particulares desde 1517 llegaban anualmente a la ciudad entre tres y cuatro mil negros; esta suma llegó a ser mayor entre 1595 y 1615 cuando la ciudad fue el único puerto de América autorizado para recibir cargamentos de asentistas y tratantes (Restrepo, 1997, p. 69). América se convirtió en el gran mercado de esclavos africanos, y fue en el Nuevo Mundo y bajo dominio europeo donde más prosperó la esclavitud. Era tanta la población negra en Cartagena que el cabildo de la ciudad en 1552 decide: «por cuanto es esta ciudad había muchos negros, los cuales andan de noche después de tañida la queda, y a horas no lícitas, y hacen muchos hurtos y robos, y de ello pueden redundar daños e inconvenientes, para ello es justo poner remedio; por lo tanto se manda que después de tañida la queda ningún negro pueda andar por esta ciudad, sino fuese yendo a una casa que convenga, con un cristiano que lo lleve» (Jaramillo, 1968, p. 8).

\section{Encomienda y doctrina}

Con el fin de compensar a los beneméritos de Indias por los servicios prestados en las actividades del descubrimiento y conquista, desde comienzos del siglo XVI la Corona adoptó a través de las capitulaciones el repartimiento de tierras y de la población indígena presente en ellas, a través de la encomienda. Con esta forma de organización paralela a la conquista temprana, los naturales entraron al servicio de los conquistadores mediante la prestación de servicios personales en el cultivo de las tierras, la guarda de los ganados, el laboreo de las minas, la ejecución de obras públicas y en general toda clase de actividades económicas (Ots-Capdequí, 1965, p. 25).

La encomienda permitió la consecución simultánea de dos logros: la sujeción de la población indígena para su inmediata explotación por parte de los conquistadores y la toma de posesión, en nombre del rey, de los territorios nuevos. Se sabe que la encomienda recrudeció su potencial violencia en los territorios de México y Perú. Esto obedecía a la existencia, en ambos lugares, de importantes civilizaciones indígenas, cuya densidad demográfica abría la posibilidad de elevar enormemente la masa de tributación para cada conquistador (González, 1979, p. 17).

Inicialmente, la encomienda tuvo carácter temporal. Al vencer el plazo de tiempo por el cual habían sido concedidas o a la muerte del encomendero, los indígenas se incorporaban a los repartimientos de la Corona. No obstante, en la primera mitad del siglo XVI se hizo costumbre consentir -por vía de disimulación- que la viuda y los hijos del encomendero siguieran disfrutando de los indios a la muerte de su causante. La Real provisión de 25 de marzo de 1536 sancionó dicha práctica y desde entonces las encomiendas se repartieron por dos vidas - al mayor de los hijos varones; en su defecto a la hija y en último término a la mujer- (Ots-Capdequi, 1965, p. 26). La encomienda duro hasta la segunda mitad del siglo XVIII ${ }^{6}$.

Esta primitiva forma de agrupamiento y reducción de la mano de obra indígena fue el nicho fundamental de la evangelización. Es decir del proceso de cristianización de los infieles el cual pasó por varias etapas marcadas por las acciones de la conquista, la adopción de distintas formas administrativas, la reducción de la población indígena y las deliberaciones

6 Por Real Cédula de 8 de abril de 1629 se concedió una vida más en el disfrute de las encomiendas, mediante el pago de una composición. Y todavía el 10 de octubre de 1704 se permitió una cuarta vida, mediante el pago de dos annatas para los gastos de guerra (Ots-Capdequi, 1965, p. 27). 
de la teología sobre el carácter racional de las poblaciones nativas. Entre ellas merecen destacarse la ocupación del territorio por nuevas conquistas, la esclavitud y extinción de las poblaciones nativas; las medidas de protección de los naturales como las Leyes de Burgos de 1512, los debates sobre el tratamiento a los nativos, las disposiciones para proteger la mano de obra indígena y, particularmente, las Leyes Nuevas de $1542^{7}$.

En el marco de las muchas disposiciones para mantener la encomienda, el clero Regular especialmente, se hizo cargo de la cristianización de los indios en las doctrinas establecidas dentro de la dicha organización territorial, con los privilegios para ejercer como curas de almas. La enseñanza del evangelio tuvo un papel fundamental en la administración de la población nativa mediante la formación de hábitos y costumbres de acuerdo con la organización social y política española. Para cumplir con este precepto los españoles que poseían un repartimiento de indios deberían mantener un clérigo o religioso que enseñara a los indios la doctrina cristiana.

Luego de que se haya hecho la pacificación dice la ley $1^{a}$, título VIII, libro VI el adelantado, gobernador y pacificador, reparta los indios entre los pobladores, para que uno se encargue de los que fuese de su repartimiento y los defienda y ampare, proveyendo maestro que les enseña la doctrina cristiana y administre los sacramentos (Bohórquez, 1956).

La acción del cura doctrinero en las llamadas escuelas doctrinales encargadas donde la catequización y enseñanza de la Fe sentó las bases de una nueva cultura entre la población nativa de América. Pese a que su experiencia no constituye un antecedente en el surgimiento posterior de la escuela pública, fue instrumento de gobernación y disciplina política.

El cura doctrinero fue un personaje central en la organización de la «nación de los indios», "por cuanto el estar los indios congregados en pueblos es cosa tan necesaria para vivir política y cristianamente que sin este fundamento no se hace cosa, mándesele al sacerdote o religioso que no consienta que se despueble indio alguno y al que se huyere lo reduzcan por ministerio de los alcaldes del pueblo y alguaciles» (Pacheco, 1959, p. 166).

Las doctrinas, como las parroquias y misiones, estaban adscritas a las diócesis; pero a diferencia de las parroquias cuyo propósito era congregar a la población blanca mediante la atención del párroco perteneciente al clero secular, las doctrinas, constituidas en territorio de las encomiendas o como resultado de las misiones estaban a cargo de un religioso quien ejercía su labor entre los nativos. Incluso, con la facultad para administrar los sacramentos cuya competencia era de los clérigos formados en los Seminarios. El doctrinero como el misionero gozaba de amplias facultades por la importancia de su cometido. Si bien parroquia y doctrina dependían del obispo lo particular del trabajo de estas últimas, dependió -durante varias décadas- de las particulares disposiciones de cada Orden (Gutiérrez, 1992, p. 276).

Para cumplir con las labores asignadas por la Corona a los regulares en 1529 llegaron a Santa Marta un grupo de frailes de la Orden de Predicadores acompañando a los conquistadores; en 1541 se hicieron presente 10s mercedarios; en 1550 arribaron a Santafé algunos franciscanos con los primeros Oidores; posteriormente agustinos y desde 1575 los jesuitas.

Llegada una Orden religiosa al Nuevo Reino de Granada trataba, no sin oposición (ya fuera de encomenderos, autoridades, otras Órdenes religiosas o el clero secular), de establecer un convento al lado del cual levantaba escuela donde los indios debían ser

7 «Las Leyes Nuevas se referían en particular a la encomienda, la esclavitud y la administración. [Ellas] prohibían que se utilizara el concepto de guerra justa como excusa para la esclavitud y declaraban además que había que liberar a cuantos habían sido esclavizados ilegalmente». 
enseñados de acuerdo con los principios doctrinales. Las ordenanzas para la doctrina y enseñanza de la religión de los indios de la Provincia de Cartagena en 1555 y 1as ordenanzas de Tunja en 1575-1576, por ejemplo, son una muestra de la legislación producida por las autoridades locales para organizar dichas escuelas doctrinales.

$1^{o}$ que en todos los pueblos de su Magestad y encomenderos de esta provincia de Cartagena haya escuelas en partes principales y a donde concurran e acudan los indios de pueblos pequeños en que cada cual de ellos buenamente, no se sufre haber escuela. $2^{\circ}$ item, dijeron que conviene que para solo efecto de decirse e oírse la doctrina se haga una iglesia en 1os dichos pueblos. $3^{o}$ ítem, que sean persuadidos y atraídos que vayan a misa e doctrina los domingos y primeros días de Pascua los trabajadores, sino dieren alguna excusa competente al de la doctrina. $4^{\circ}$ ítem, que los hijos de los caciques e principales, que han de suceder en los estados, que los que tengan consigo el sacerdote para los doctrinar, y mostrar y encaminar en las cosas de la fe y policía (Mesarza, 1955, pp. 69-74).

Las ordenanzas de Tunja establecieron para esa provincia la obligación de que encomenderos e indios debían tener para con el cura doctrinero relativo a estipendio y otras obligaciones y en general a las formas de organización de las doctrinas como de las escuelas donde se impartiría la enseñanza de la religión y la lengua española.

a) Primeramente ordenaron y mandaron que los encomenderos de indios de dicha ciudad de Tunja, en cumplimiento de lo que son obligados, tengan doctrina competente de sacerdote que doctrine e industrie los indios, sus encomendados, en las cosas de nuestra santa fe católica, cada uno conforme a lo que se le repartiere.

b) Y porque todo intento de los dichos señores es que los evangélicos se plante en los indios, se ordena y manda que los caciques, capitanes e indios, todos exhiban ante el religioso o sacerdote todos los niños y niñas y muchachos hasta diez y seis años... Estos acudan siempre a la doctrina y en esto no haya falta y tenga de ello especial cuidado en que los hijos de los caciques y de los principales sean bien doctrinados y enseñarles a leer y a escribir (Friede, 1968, pp. 140-162)

El cura doctrinero elaboraba el padrón de los pueblos de indios que tenía bajo su jurisdicción en el cual registraba el nombre de los nativos agrupados por caciques, discriminándoles por sexo y edad con el fin de contribuir a la contabilización de los tributos de los indios y cerciorarse de su asistencia los días de doctrina, a la misa dominical y días de fiesta. A los indios que faltaban se les castigaba físicamente mientras el cacique debía pagar multa representada en especie. En la misa después del evangelio, debía hacer el doctrinero una breve homilía; en ella debería insistir en aquellas doctrinas en que menos firmes están los indios como la integridad y efectos de la confesión, inmortalidad del alma, premio y castigo eterno y temporal del purgatorio y la real presencia de nuestro salvador en la eucaristía (Pacheco, 1964, p. 494).

El procedimiento de la doctrina consistía en reunir los indios en el bohío donde funcionaba la escuela doctrinal o en el atrio de la iglesia o capilla y allí, a viva voz los indios repetían las palabras del cura doctrinero o sacristán quien iba rezando las oraciones o diciendo los mandamientos o misterios de la Fe. En las escuelas doctrinales el objetivo 
del saber religioso era «romper la idolatría de los naturales y reemplazarla por la creencia en un nuevo Dios» (Martínez-Boom, 1982).

Lo primero que se hace, dice el padre Asencio al tratar de $1^{a}$ provincia de Santafé, es poner por memoria y sacar todos los niños y muchachos varones y hembras y estos han de ir cada día a hora de misa a la iglesia, donde después de haber dicho la misa el sacerdote, dice la doctrina cristiana, rezada o cantada como mejor se amañe o le parece, y después de haberlas rezado se van a la casa hasta la tarde y vuelven a la hora de víspera, y se les dice la doctrina que es dicho (Romero, 1960, p. 464).

El fiscal a su vez, durante una o dos horas por la mañana se encargaba de repasar la doctrina señalando a cada uno lo que debía aprender de memoria; a los que no respondían en alta voz o se equivocaban se los castigaba con una vara o azote. Los sábados el doctrinero verificaba el adelanto de los neófitos. Repetir y memorizar eran las formas típicas del trabajo de evangelización. El éxito de esta instrucción fue tal que Pilar Gonzalbo cuenta como se intentó aplicar entre otras comunidades étnicas.

En busca de una solución más duradera -dice la autora- se pensó en realizar una intensa labor evangelizadora, similar a la que tan buenos resultados había dado para lograr la sumisión de los indios. Reales cédulas recomendaron que se fomentasen las buenas costumbres de negros, mulatos y zambaigos, mediante la instrucción religiosa y la sujeción al trabajo. Los jesuitas fueron agentes eficaces en esta tarea, hasta el punto de que muchos dueños de haciendas reclamaban la presencia de los misioneros de la Compañía como el mejor sustituto de látigos y cadenas. En 1586, el prefecto del colegio de Veracruz informaba:

Han salido los nuestros en misiones por esta tierra y comarcas; $y$ en las partes donde han ydo se ha visto notable fructo en la gente humilde, como son sclavos y otros deste xaez. Que siendo antes indómitos, que destruyan a sus amos, assi en ser fugitivos como en robarles sus haziendas y haxer otros insultos, sus propios amos confiessan que después que han ydo a tratarlos los nuestros los hallan quietos y domésticos (Gonzalbo, 2001, pp. 436-437).

Con fin de establecer la disciplina eclesiástica entre Regulares y Seculares el Concilio de Trento, celebrado entre el 13 de diciembre de 1545 y el 4 de diciembre de 1563, se ocupó particularmente de la formación de unos y otros en los llamados seminarios conciliares. En consonancia con sus disposiciones la Asamblea determinó que los aspirantes a cumplir con el oficio de doctrineros, además del saber necesario para enseñar las verdades dela Fe, debían «tener en cuenta el linaje para acreditarlos como hijos de cristianos viejos, libres de toda mancha de moros, judíos y penitenciados por el Santo Tribunal de la Inquisición, de legítimo matrimonio y de salud perfecta» (Restrepo, 2010, p. 72).

A partir de la fundación de la arquidiócesis de Santafé sus dos primeros arzobispos, fray Juan de los Barrios y fray Luis Zapata de Cárdenas, iniciaron la aplicación de las medidas dispuestas por Trento y Lima en lo relacionado con la formación de los eclesiásticos. No obstante fue Trento el encargado de establecer los mecanismos más contundentes para la acción pastoral.

La historiografía tradicional suele conectar el proceso de colonización como una descripción dual según la cual al lado de la espada conquistadora estaba la cruz del 
cura doctrinero que venía a evangelizar ${ }^{8}$. La imagen no es precisa porque el proceso de colonización fue realmente ambiguo y azaroso. En otras palabras, lleno de claroscuros. Predicación, evangelización y catequización fueron instrumento y razón para la penetración, control y dominio de las tierras como de los hombres del nuevo orbe.

\section{Modos educativos. Los catecismos}

Desde comienzos de la evangelización los religiosos doctrineros, generalmente provistos de los rudimentos de la Fe pero sin la formación suficiente en los principios de la moral y de los dogmas, ejercían su labor de acuerdo con los principios doctrinales del Orden. La diversidad de ideas y normas para llevar a cabo su labor se reflejó por varias décadas en el desconocimiento de la Fe por parte de los nativos pese a las recomendaciones de las diócesis y las normas dictadas por los pocos concilios llevados a cabo. La distancia de los conventos mayores y las largas jornadas impedían además la comunicación con los pocos letrados llegados a sus propias doctrinas.

Frente a esta situación advertida en la América española por parte de las autoridades eclesiásticas de Lima y México, ciudades donde se concentró la gobernación de eclesiástica dirigida desde la diócesis de Sevilla, el Concilio de Trento - cuyo objeto fue restablecer el orden eclesiástico, definió que todos los infieles debían ser instruidos en la Fe a través del mismo manual: el Catecismo de Universal traducido inicialmente del latín a lenguas romances y, posteriormente, mediante las disposiciones conciliares en las distintas regiones, a las lenguas de los indios.

El trabajo iniciado tímidamente desde finales del siglo XVI en la América Hispana cobró importancia a partir de la definición propuesta por la Compañía de Jesús y aprobada por Trento sobre la teoría de la Gracia. En suma la decisión de que los indígenas en razón de sus prácticas podrían como la población blanca recibir el sacramento de la confesión.

La decisión del Concilio, definió no solo la traducción del catecismo a las lenguas de los indios, acreditó la práctica de la confesión e hizo de ella el principal instrumento de conocimiento sobre la vida y moral de los infieles en todo el Orbe.

En consonancia con la importancia de la lengua en calidad de vínculo entrela enseñanza del evangelio en las doctrinas, la producción y el trabajo de los indios, la corona española adoptó en 1550 el castellano como la lengua oficial de la evangelización «debido a la diversidad de lenguas y dialectos indígenas»; no obstante seguía considerando «difícil aun en la perfecta lengua de indios explicar bien y con profundidad los misterios de nuestra santa fe, [hecho] que no es posible sin cometer grandes disonancias e imperfecciones (Leyes de Indias, 1841). Es decir, los errores que pudieran cometerse por la dificultad para expresar misterios tan elevados [y] cosas tan altas (Lee, 1964).

En el mismo año por medio de una Real Cédula al Provincial de la Orden de San Francisco mandó y «encargó que proveáis como todos los religiosos de nuestra Orden que en esa provincia residen, procuren por todas las vías a ellos posibles, de enseñar a los indios de esta tierra nuestra lengua castellana (Friede, 1955, t. X, p. 275).

Desde 1575, Fray Dionisio de Sanctis obispo de Cartagena elaboró un primer catecismo. Se trató de una breve suma de demandas y respuestas para mayor retención en la memoria y más aprovechamiento de los nuevos en la Fe ${ }^{9}$. En 1576 Fray Luis Zapata

$8 \quad$ Con el soldado y el colono iba el capellán, con Jiménez de Quezada, que trepa hacia la sabana de Bogotá en busca del Dorado, va el Padre Domingo de 1as Casas que catequiza y bautiza (Mesa, 1973, p. 305).

9 Breve y muy sumaria instrucción de utilidad para enseñar los nuevos en la fe, de lo que creer y 
de Cárdenas segundo arzobispo de Santafé elaboró el catecismo para curas el cual tuvo poca difusión por la disolución del Seminario de San Luis de Francia donde el vicario aspiraba darlo a conocer entre los diez y nueve colegiales que se formaban. Según Fray Alonso Zamora el compendio fue mandado a escribir al bachiller don Miguel de Espejo y traducido por nuestro religioso, según 1as lenguas de cada gobernación [...] sirvió mucho para la enseñanza (Zamora, 1701, p. 328).

Pese a los esfuerzos desarrollados por varias Órdenes religiosas como a los mandatos de la Arquidiócesis, entre 1580-90 las autoridades constataban que después de tres décadas de la acción evangelizadora el sometimiento y la organización de los indígenas no se había cumplido aunque la disminución de los nativos -como dijera Germán Colmenares (1978)- alcanzaba un 80 \%. Según los informes el proceso de la evangelización considerado superficial solo garantizaba la adhesión nominal de los nativos a la religión católica porque su compromiso estaba sujeto a las sanciones impuestas (Martínez-Boom, 1982). En este mismo sentido las costumbres no habían cambiado en lo fundamental, todas las formas de vida y de trabajo preexistentes a la conquista se conservaban.

Antes de concluir el siglo XVI arribó a la capital don Bartolomé Lobo Guerrero como tercer arzobispo quien convocó al análisis de la situación sobre la enseñanza de la lengua y la actividad de los doctrineros, el relajamiento y la falta de moral de los clérigos empeñados especialmente en actividades lucrativas mientras los indios y pobladores se hallan -según su opinión- en estado de ignorancia y desconocimiento de los fundamentos de la religión católica.

Muchas provincias por ejemplo la de Tunja, no habían tenido curas doctrineros durante una década (1570-1580); la Real Audiencia no había cumplido con la organización de la catequización ni la sujeción de clérigos y religiosos; las constantes confrontaciones por el poder entre la iglesia y los encomenderos desvirtuaba el papel de la primera.

Según informaba al Rey el Licenciado Pedro de Zorrilla oidor de Santafé, los indios estaban tan ignorantes como al principio de la conquista. Los religiosos descuidaban las doctrinas y muy pocos habían aprendido las lenguas indígenas, por esto se veían obligados a enseñar la doctrina en castellano, $y$ los indios la repetían sin entenderla, como papagayos. Algunos clérigos y frailes además daban mal ejemplo a los naturales, conviene añadir que los provinciales seleccionan a los religiosos que han de venir a los indios, pues sucede que los reclutan como hacen los capitanes con los soldados y así no vienen sino los que no quieren sujetarse a la regla o pretenden hacer fortuna (Pacheco, 1959, p. 42)

La Real Audiencia denunciaba que muchos indios ladinos no tenían de cristiano sino el nombre. Como argumentaran Jorge Juan y Antonio Ulloa en las Noticias Secretas de América, el relajamiento moral de las costumbres de las Órdenes religiosas particularmente, dominicos y franciscanos, era notable.

Los conventos están sin clausura, y así viven los religiosos en ellos con sus concubinas dentro de las celdas... Todo esto, que parece mucho, es nada en comparación de lo demás que sucede... Lo que se hace más notable es que los conventos están reducidos a públicos burdeles, como sucede en las poblaciones cortas, y que en las grandes pasan a ser teatro de abominaciones inauditas y execrables vicios (Liévano, 1973, p. 303).

obrar y de que se han de apartar para ser buenos cristianos (De Sanctis, 1962). En la parte final del catecismo se incluye una cartilla para enseñar a leer y la doctrina cristiana, abecedario y silabario que abarcan todas las combinaciones principales de silabas, para llegar al conocimiento y lectura de las palabras. Contiene además las oraciones que deben ser aprendidas por los indios. 
Ante el relajamiento moral de las comunidades religiosas y el estado en que se hallaba la catequización, el vicario, respaldado por la Compañía de Jesús celebró en 1602 la junta a través de la cual impuso el catecismo mosca como manual obligatorio de los doctrineros de la Provincia ${ }^{10}$. Como lo advirtieron las autoridades presentes, la traducción del Catecismo de Trento, a través de su versión Limense, realizada por el Padre José Dadei, era fiel a las verdades de la Fe y a los fundamentos de la moral como lo confirmó el III Concilio Limense organizado por la Compañía de Jesús (Romero, 1960, p. 254).

Autorizado el compendio, la Arquidiócesis convocó a examen a los curas doctrineros quienes debían demostrar la solvencia necesaria para aplicar el manual, mientras dos religiosos jesuitas de camino a las doctrinas probaban -en la práctica- la competencia de los evangelizadores sobre los fundamentos del catecismo en la lengua de los indios. De esta manera Lobo Guerrero garantizaba la enseñanza del catecismo en las provincias de Tunja y Santafé y la Gobernación de Popayán.

\section{Regalismo borbónico}

A partir de la segunda mitad del sigo XVIII se registra un cierto movimiento de reorganización institucional que toca diversos lugares de la vida política y social del mundo colonizado por España. Después del ascenso de Carlos III se pone en marcha un conjunto de orientaciones tendientes a reordenar la economía y la administración. John Leddy Phelan utiliza una expresión que se podría considerar como afortunada al momento de describir esta dificultad, y lo hace a propósito del programa económico y fiscal de Carlos III, la llama modernización defensiva, es decir, una forma de introducir cambios modestos y cautelosos en favor de los intereses peninsulares sobre sus gobernados.

[...] después de 1763, el primer intento de modernización defensiva en gran escala se efectuó en el virreinato de México [...] A fines del decenio de 1770 y a comienzos de 1780 José de Gálvez trato de aplicar el modelo de su experiencia mexicana a los virreinatos de Nueva Granada y Perú. Si José del Campillo y Cossío fue el principal diseñador del programa de modernización defensiva de Carlos III, Gálvez constituyó su principal ejecutor [...] Los objetivos y las tácticas empleadas por Gálvez en México fueron imitados, con pequeñas variaciones, por el funcionario que nombró un decenio después para la Nueva Granada. Creación de un monopolio de tabaco rentable, administración directa de la monarquía del sistema fiscal, expulsión de los criollos en los cargos públicos y restricciones al poder del virrey: todo esto se había ensayado ya en México (Phelan, 1980, p. 21).

La experiencia del regalismo borbónico significaba introducir formas de gobierno algo más liberales, buena parte del tiempo colonial estuvo destinado a una economía de extracción, principalmente de metales preciosos que fueron embarcados hacia España, fue tarea central del regalismo incorporar nuevos elementos de gobierno económico cuya modernización hizo evidente los discursos de la economía política y de la ilustración que clamando por el cambio justificaban a su vez la represión a quienes se oponían a actualizarse, en particular cuando implicaba remover prácticas tradicionales de gobierno y trabajo.

10 De acuerdo con la reseña del padre Zamora, un catecismo del sacerdote dominico Pedro Francisco de la Cruz es utilizado para la enseñanza de nuestra santa fe católica dispuso un breve catecismo, en donde en pocas hojas comprendió la más alta teología, dándola a beber tan clara como el agua para la instrucción de los pequeñuelos. Se hicieron muchos traslados que se repartieron por todo el reino (Zamora, 1701, p. 434). 
Por supuesto que estos procesos no se pueden leer de manera lineal se trató de ejercicios gubernativos algunas veces estrictos ${ }^{11} \mathrm{y}$ muchas veces abordados con amplia laxitud dada la distancia geográfica entre soberano y súbditos, atravesados siempre por urgencias, azares y tensiones de todo tipo. España y América se encontraban sumidas en el letargo de una vida sedentaria y una mentalidad llena de creencias calificadas como torpes alucinamientos propios del vulgo, al respecto Benito Jerónimo Feijoo decía que España estaba atrasadísima, al tiempo que en la Provincia de Antioquia el visitador José Antonio Mon y Velarde comparaba su precariedad con las regiones africanas. Consideraciones que ponen en tensión la idea convencional de que los procesos ocurrían primero en Europa y en España antes de acontecer en las periferias.

En todo caso a partir de la segunda mitad del siglo XVIII podemos percibir un cierto movimiento de reorganización institucional que toca diversos lugares de la vida política y social del conjunto de las colonias españolas. Después del ascenso al poder de Carlos III, se pone en marcha en la metrópoli y en la periferia un conjunto de orientaciones tendientes a reordenar la economía y la administración de la vida en su conjunto. El propósito de esta modernización «era convertir los reinos de ultramar en verdaderas colonias que produjeran el máximo de ingresos para la metrópoli convirtiendo a los reinos de Indias en un verdadero imperio económico» (Phelan, 1980, p. 33).

En las primeras filas de esta preocupación encontramos a intelectuales pragmáticos y políticos ilustrados que hicieron las veces de consejeros y asesores del rey. Los nombres de Pedro Rodríguez de Campomanes, Bernard Ward, el Conde de Aranda (Pedro Pablo Abarca de Bolea), Francisco Cabarrús Lalanne, Gaspar Melchor de Jovellanos, Antonio José Cavanilles y Palop, José Bernardo de Gálvez y Gallardo, José del Campillo y Cossío, entre otros, hicieron parte del selecto grupo que fue calificado como de denodada voluntad y amor desmedido por la patria, responsables de arrancar al hombre de la ignorancia, de la indigencia material, restituyendo el sentido de su dignidad y devolviendo a cada región la felicidad pública y la prosperidad económica.

En el Nuevo sistema de gobierno económico para la América (Campillo, 1789) se define el gobierno económico como «la buena policía, el arreglo del comercio, el modo de emplear civilmente a los hombres, el de cultivar las tierras, mejorar sus frutos, y en fin, todo aquello que conduce a sacar el mayor beneficio y utilidad de un país» (1789, p. 3). La principal máxima para cumplir ese programa, era la reducción de los indios a la vida civil y, con «benignidad y dulzura», el fomento de la industria y la agricultura en esas poblaciones. Según este ilustrado los remedios para llevar a los indios a la vida civil eran dos: la unificación del vestido y del idioma. Con la introducción entre los indios del «traje español entero» esperaba no solamente un «mejor orden del nuevo establecimiento de Gobierno Económico», sino un aumento considerable del comercio por el consecuente crecimiento del consumo (1789, p. 124). Igualmente, la extensión del uso de la lengua española debía permitir que los indios se parecieran «en todo españoles, así también aficionándose cada día más a la Corona y patria de quienes son vasallos» (1789, p. 138). La enseñanza del castellano formó parte del sistema diseñado por Campillo y Cosío en clara alusión a objetivos de promover y dirigir la utilidad de los indios para toda América.

11 Fueron particularmente estrictos con los jesuitas, con los libros, con la clasificación de pueblos, villas y ciudades. 
No es menester en una monarquía que todos discurran ni tengan grandes talentos. Basta que sepa trabajar el mayor número, siendo pocos los que deben mandar, que son los que más necesidad de luces muy superiores [...] la muchedumbre no ha de necesitar más que fuerzas corporales y docilidad para dexarse gobernar; y así lo que se acumula como una gran nulidad en los indios, no lo miro yo como tal, sino antes bien como una especialísima ventaja, útil y provechosa para muchas cosas [...] en el supuesto de que los indios tengan las potencias tan limitadas como se dice, me parece que esta es la circunstancia más feliz que puede haber para los fines políticos del gobierno; pues de este modo se podrá con toda facilidad hacer de ellos aquello que se quiera, habiendo hombres que sepan y alcancen oportunamente valerse de esta ventaja para dirigirlos al bien suyo y al del Estado, que es únicamente lo que proponemos, promovemos y tratamos (Campillo, 1789, pp. 91-92).

Lo que estaba en juego era el impulso de un horizonte práctico que insistía en desperezar la economía de España, por lo menos es la expresión que usa Rodríguez de Campomanes para referirse al cambio de las costumbres a favor de una vida que posibilitara mayores producciones del erario regio. Una clara alusión al mercantilismo de la época que funcionó como una racionalidad capaz de colocar a la Corona en el centro de la relación entre súbditos y rey con el objeto de aumentar el poderío y riqueza del soberano. Esta política propone no solo aumentar y reordenar los impuestos existentes hasta el momento, sino también aumentar la producción económica mediante la introducción de cambios tecnológicos, entre ellos: «la inclusión de la ciencia nueva en los estudios universitarios, las expediciones mineras a México, Nueva Granada y Perú, la expedición botánica de la Nueva Granada en $\mathbf{1 7 8 0}$, la creación de ramos de la sociedad económica de Amigos del País en diversas capitales de las indias, y la rápida introducción de la vacuna contra la viruela» (Phelan, 1980, p. 33).

De las instituciones existen dos representaban la jerarquía tradicional que requería modernización: la institución del virreinato y el papel estratégico de la iglesia. Dos virreinatos gozaron de especial importancia, el Virreinato de Nueva España que existió entre 1535 y 1821, y el Virreinato del Perú entre 1544 y 1824; y otros dos se erigieron durante el gobierno de la casa Borbón, el Virreinato del Nuevo Reino de Granada en dos periodos entre 1717-1724 y 1739-1819, y el Virreinato del Río de la Plata entre 1777 y 1811.

La economía virreinal era realmente precaria, no había mercado de trabajo sino un sistema coercitivo para procurarse trabajadores. El mercado de tierras era también una utopía, la tierra era del rey quien la cedía a terceros (conquistadores, municipios, religiosos o las retenía como propiedades realengas dándola en usufructo a los indios). La monarquía era propietaria de todo (suelo, subsuelo, mano de obra indígena, comercio, etc.), y en esa posesión residía su potestad interventora. Cedía sus derechos a los particulares por vía de graciosa merced pero conservaba todos los derechos pecuniarios (Lucena, 1992). Había también poco circulante monetario porque España realizaba una extracción constante de oro y plata. El dinero que circulaba era escaso para la población existente. No había grandes capitales y los ricos lo eran por su patrimonio, no en dinero sino en propiedades, minas, cabezas de ganado, piezas de esclavos, en fin. Si alguien requería hacer transacciones recurrían a prestamos con un interés anual del $5 \%$, hasta el punto de que casi todos los terratenientes tenían gravadas sus posesiones con censos y capellanías ${ }^{12}$.

12 Exteriormente la capellanía consiste en la afectación de una suma de dinero o la vinculación de un bien para que con sus intereses o su renta se remunere a un capellán encargado de decir misas por el alma 
El crédito proporcionado por el sistema de censos y capellanías posee características institucionales demasiado rígidas y estas apoyan, a la vez que condicionan, un marco tradicional de sociedad agraria [...] El estudio de los censos como fuente de crédito permite comprender el mecanismo más íntimo de esta formación de las haciendas, lo mismo que las limitaciones del sector agrícola colonial frente al de los comerciantes y los mineros (Colmenares, 1979, p. 130).

El dinero no servía para adquirir alimentos y los tenderos usaban frecuentemente vales o señales convencionales para el cambio, las vueltas o el sencillo. El reformismo borbónico fue la nueva forma que asumió la política del imperio español cuyos lineamientos políticos, económicos y sociales pueden definirse en los siguientes términos: la introducción de la economía en el nuevo ejercicio político de la Corona, la redefinición del estatuto de las colonias americanas que se consolidan como unidad territorial, la definición de una nueva imagen del Estado que modificó la índole de la monarquía haciéndola aparecer como régimen despótico ilustrado y la aparición de la población como problema específico del gobierno. El despotismo es, claramente, un gobierno económico.

\section{Una señal de partida. La expulsión de la Compañía}

Antes de la expulsión de la Compañía de Jesús, en agosto de 1767, existían prácticas de enseñanzas dispersas y restringidas. La instrucción doctrinal, por ejemplo, se ejecutaba en las doctrinas que hacían parte de la encomienda; la enseñanza doméstica en la casa del discípulo que podía pagar un preceptor particular; el artesano utilizaba su taller como lugar de enseñanza al igual que el peluquero o el sastre, es decir, enseñanzas llevadas a cabo en diversos lugares sin que ningún espacio en particular fuera identificado como predominante. $\mathrm{Y}$ enseñanzas restringidas en el sentido de estar dirigidas a ciertas capas sociales denominadas como "gentes principales y beneméritas» principalmente en Colegios y Seminarios a cargo de órdenes religiosas.

Por esta razón, los hijos de Loyola habían alcanzado a regentar en la capital del Nuevo Reino de Granada y en las capitales de las Provincias de Tunja, Popayán, Cartagena y Antioquia, además de las cabezas de partido, el caso de Mompós, Pasto, Buga, Vélez, Pamplona y Honda algunos Colegios y Seminarios. El acontecimiento político de la expulsión produjo por tanto un vacío que era necesario suplir y su impacto abarcó a todos los reinos de América Hispánica, fue de hecho un gesto visible de ejercicio del poder soberano frente a una de las instituciones representativas del establecimiento español durante la colonia. La estrecha colaboración de los poderes temporal y espiritual y la subordinación de la política a los fines religiosos se tradujeron en ventajas tangibles para la monarquía (Krebs, 1992, p. 68), que la expulsión puso en tensión a favor de otras prácticas que en principio podemos nombrar como más seculares. En todo caso el extrañamiento fue claramente un acontecimiento cosmopolita que demandó capacidad de

del fundador, sus deudos y las almas del purgatorio en general [...] En algunos casos la imposición de una capellanía servía para mantener intacta una propiedad que de otra manera se habría visto fragmentada innumerables veces por la concurrencia, de los herederos [...] Podía servir también para procurar un medio de vida para un pariente próximo o inducirlo a recibir las órdenes sagradas. Pero en cualquier caso las capellanías no eran otra cosa que una institución crediticia con ropaje canónico (Colmenares, 1979, p. 137-138). 
reacción frente a una contingencia común. Las consecuencias del extrañamiento abarcan un amplio espectro de efectos políticos, pastorales, económicos, culturales, misionales y educativos.

No es exagerado valorar la expulsión como una señal de partida que sirvió de impulso a la aparición de la escuela pública. De hecho, la legislación posterior al extrañamiento estuvo dirigida para todos los reinos de España y dio origen a un andamiaje jurídicoadministrativo capaz de reglamentar el «magisterio de primeras letras». Se inicia una injerencia directa del monarca en la provisión de cátedras de maestros de primeras letras, en particular, disponiendo la transferencia de temporalidades a «la merced y libre disposición del Soberano».

[...] En 1770 el Cabildo de Montevideo - a pocas décadas de fundada la ciudad-se enfrentó a la necesidad de instalar una escuela pública, ya que la escuela que existía por entonces - a cargo de la orden de los jesuitashabía sido clausurada [...] Por tal razón, las autoridades determinaron que en el local de la Residencia se instalase una escuela municipal (Bralich, 2014, p. 239).

La educación doméstica deja de estar en manos de la familia o de la iglesia y pasa, progresivamente, a la intervención pública. Si bien la escuela es quizá la primera institución estatal del saber, sus conexiones con la iglesia fueron desde sus inicios muy visibles e incluso difíciles de separar. Con ello se ratifica que en sus comienzos dicha institución no tuvo como tarea fundamental la educación, el conocimiento o la ilustración de los individuos sino el amoldamiento, especialmente de los niños pobres. Una escuela diferencial y unificada con la que inician los procesos de escolarización social.

\section{La emergencia de la escuela pública}

La aparición de la escuela pública en la sociedad Hispanoamericana es un acontecimiento reciente, de algo más de dos siglos, cuyas huellas podemos encontrar entre un inmenso y desordenado arsenal de documentos. Su emergencia no fue fruto de los impulsos borbónicos, ni de las reorientaciones republicanas después de la independencia, aunque estas circunstancias sirvieron de condiciones de posibilidad para la articulación entre lo público y lo escolar. Su aparición fue el resultado del cruce de líneas de fuerza entre pobreza, prácticas de policía, la figura del niño y la utilidad pública.

Comparto con Hunter, la impresión acerca de una escuela pública que surge «a partir de la interacción imprevista de dos sistemas diferentes de problematizar y gobernar la vida, principalmente, a través de cambios en las prácticas disciplinares y en los procedimientos administrativos, en las disposiciones de espacio y de personas, en la inspección de las instituciones en el macronivel, y en la vigilancia de las almas en el micronivel» (Hunter, 1998, p. 104). Así lo que surgen son prácticas propias de la disciplina escolar y decisiones políticas del nivel gubernamental. Prácticas en doble dirección que dotan la escuela de funcionalidad al convertir lo múltiple en unidad formando, por ejemplo, lo común (unidad de lengua, religión y método), y de la misma manera, definen parámetros de comportamiento para las poblaciones con miras a la conformación futura de una sola nación y de unos fines patrióticos. Si bien la Corona contribuyó a la formación de la escuela, la aparición de esta es un punto nodal en la consolidación del Estado, así la contingencia de la escuela funcionó como una urgencia que luego se hizo necesaria. 
La atención de la Corona española y los cabildos por estas actividades y la proliferación de planes de enseñanza mostrarían una nueva preocupación del Estado por los procesos escolares, con lo cual se hacía evidente además la urgencia por resolver la cuestión de la educación luego de la expulsión de los jesuitas. La insistencia inicial decía que al fundarse casas de educación o pupilaje «estas deben hacerse con total separación de las iglesias» (C.P. 1, p. 138), a partir de aquí se abre paso una legislación, que con mayor o menor acento, vinculará al poder, en cabeza del soberano, con los dominios e intereses que antes eran privativos de la iglesia o la familia.

¿Quién podrá dudar que la enseñanza pública deba estar baxo la protección del príncipe, a quien incumbe el cuidado y superintendencia de la educación de la juventud, y baxo de cuyo patronato están todos los estudios del Reyno? [...] Un simple preceptor no puede enseñar, sin ser dotado por la autoridad Real y del Consejo, y mucho menos ninguna comunidad religiosa (Real Cédula del 14 de agosto de 1768, C.P. 2, p. 66).

La escuela que surge para esta época, no es la escuela parroquial, no es la escuela conventual, tampoco podemos asociarla a la enseñanza clandestina ni a la doméstica, mucho menos a la escuela doctrinal. Es la escuela pública de primeras letras. Una escuela que unifica lo que antes estaba disperso: las letras, la escritura, el canto, las manualidades y la vida en policía. Esta insistencia ilustra claramente la conexión que se va a consolidar entre la instauración de prácticas de policía y la institucionalización de la enseñanza de primeras letras. $\mathrm{Al}$ respecto, el personero de los vecinos de Soatá, en el expediente sobre el establecimiento de escuela de primeras letras, recogiendo en una breve síntesis el sentimiento y la idea generalizada de la época sobre la función de la educación señalaba:

La enseñanza de la juventud es el más principal ramo de la policía, el objeto más interesante de las sociedades políticas, y el que ha merecido toda la atención de los legisladores. Sin educación no pueden felicitarse los pueblos, el vicio cundiría por todas partes, las leyes, la religión, la pública seguridad y la privada, serían violadas sino se procurase desde el principio inspirar a la juventud las sanas ideas y obligaciones propias del cristiano y del vasallo (AHNB, Instrucción pública, anexo, t. IV, f. 354)

La escuela entra entonces en el orden del gobierno de la población. En lo sucesivo este se hizo posible porque empiezan a surgir gobiernos específicos sobre los niños, las almas, las familias y los territorios que comprendían la totalidad de virreinatos y audiencias de Indias. Tanto los discursos sobre la utilidad pública como la configuración de la población como problema gubernativo fueron determinantes en la delimitación de la naturaleza de la institución escolar y sus funciones «una buena policía relativa a estos asuntos, el alivio de los pobres, el destierro de la holgazanería, y la extinción de la mendicidad, la introducción del espíritu de la industria en la nación; y un nuevo sistema de gobierno económico en aquella preciosa porción de la monarquía española» (Ward, 1782).

La escuela pública fue también un espacio de reclusión y encierro de niños pobres que fueron recogidos de la calle para imprimirles máximas morales, vida en policía y rudimentos de oficios en busca de hacerlos útiles. En los estudios sobre la escuela Anne Querrien afirma que: «Si estos niños no pueden trabajar, es preciso asegurarse de que lo harán mañana. Las primeras escuelas de caridad no recogen más que a los expósitos, a los huérfanos, a los niños cuyos padres se benefician de la caja de los pobres, de la limosna 
(...) La escuela de caridad está pues destinada a los niños pobres. Muy pronto se hace obligatoria para ellos y se abre a niños no pobres, atraídos por sus métodos pedagógicos, y por la reunión de enseñanzas que generalmente era necesario buscar en estructuras diferentes» (Querrien, 1994, p. 23). Los niños pobres y no la infancia en general fueron el objeto y centro de la escuela pública, en la medida en que se descubre que son más fáciles de gobernar y dirigir ya que son la apuesta a salvaguardar.

El número de ignorantes y supersticiosos es enorme y la vida cotidiana parece signada por hábitos desoladores: «repiten lo que han hecho sus abuelos. Cultivan las tierras como se han cultivado siempre. Piensan como siempre se ha pensado. Los agobia una punzante miseria material, una total aridez espiritual, un vacío que confina con la nada» (Sarrailh, pp. 67-68), el anhelo de un género de vida distinto del acostumbrado impondrá poco a poco el pedido de que se abra una escuela pública en cada pueblo. Su carácter lo podemos definir como eminentemente público, no porque fuera gratuita $o$ financiada por la Corona, sino porque el rey reclama como «derecho suyo» su establecimiento, la definición de sus límites y usos, es decir, disponer de la instrucción requerida para hacer más gobernables a sus súbditos.

Este establecimiento tendrá una existencia práctica a través de actos jurídicos como el proferido por el Virrey José de Ezpeleta en 1789 por el que se ordenaba la fundación de cinco escuelas elementales en Bogotá o los informes provenientes de Ibagué y Neiva que informaban sobre el funcionamiento de sendas escuelas «acogiendo a la superior declaratoria en orden a la nueva creación de escuelas de niños» (AHNB, Fondo Colegios, t. II, f. 1008r), sin embargo, estaba por resolverse la cuestión del auspicio económico para su funcionamiento, aspecto central en la delimitación de su carácter público. La educación de primeras letras desde su surgimiento como cuestión pública, hasta el fin de la dominación española, se sostuvo con los fondos municipales o de propios, de las temporalidades confiscadas a los jesuitas y, de las donaciones de particulares.

Las expresiones «instrucción pública», «educación pública» $y$ «enseñanza pública» se volvieron etiqueta común en la administración y la legislación española [...] para referirse a la constitución de ese nuevo ámbito de intervención del gobierno en la sociedad [...] Al abolirse los gremios, la implementación de esta noción fortaleció además el papel de los ayuntamientos en la conducción de las escuelas elementales (Roldán, 2014, p. 77-78).

El carácter público de la escuela y de la instrucción derivada de ella pondrá en escena un conjunto de criterios activos: utilidad, incitación y disciplinamiento, asuntos cercanos a un nuevo espacio social para la educación. Eugenio Roldán recuerda que en lenguaje de la última década del siglo XVIII e inicios del XIX las expresiones «instrucción pública» y «educación pública» no son sinónimas: «instrucción pública» remite a la instrucción general que posee el pueblo mientras que «educación pública» tiende a referirse a la enseñanza que se imparte en los establecimientos escolares y no en el ámbito doméstico (2014, p. 75).

Las «Bases para la formación de un plan general de instrucción pública» propuesta por Jovellanos como asesor del monarca en 1809 reitera el carácter público de la instrucción referida al avance de una educación supervisada por quien gobierna sobre ámbitos tradicionalmente domésticos: Esta buena dirección dada en la educación pública no solo perfeccionará las facultades físicas en los ciudadanos, sino que corregirá los vicios y malos hábitos que se hayan contraído en la educación privada (Jovellanos, 1858, p. 267). 


\section{Planes de escuela y los intentos de unificación}

Los primeros intentos de regular y unificar estatalmente la práctica de la enseñanza pública pueden describirse desde tres fuentes discursivas complementarias: los planes de escuela, los requerimientos sobre los maestros delimitados desde ámbitos jurídicos, y el impulso al método mutuo de enseñanza, acompañado del interés por las Escuelas de la Patria y por el uso de manuales a comienzos del siglo XIX. Cada uno de estos aspectos implicó un esfuerzo regulatorio por parte de la Corona que más allá de lograrse o no puso en marcha la función estratégica de la instrucción pública.

La escuela como escenario privilegiado para la enseñanza fue apareciendo esporádicamente en los discursos de quienes recomendaban la instrucción de los menores pobres como el mejor paliativo de las miserias y las necesidades del Estado. En este proceso de edificación del espacio escolar, aparece lo que se conocerá como «Planes de Escuela» (Martínez-Boom, 2011), documentos que contribuyeron enormemente a la objetivación de este nuevo lugar. La forma documental de la época fue el expediente que en términos generales alude a un trámite formal gubernativo, judicial, eclesiástico, militar, hacendatario o inquisitorial, que podía comenzar y concluir en una misma oficina, o en su defecto pasar por muchas; algunos expedientes circulaban en una misma región otros viajaban de lugar en lugar a centenares de kilómetros de distancia; algunos duraban un día otros, decenas de años. Desde el punto de vista diplomático el elemento distintivo que fija la naturaleza del expediente es el asunto jurídico que le da existencia, de ahí que lo integre un conjunto de pasos protocolarios que comprometen a diversas instancias administrativas.

A la luz del estudio documental se comprueba que el espacio o superficie de emergencia en donde por primera vez se anudaron unas precisiones fundamentales sobre la escuela y la enseñanza fue el plan de escuela para muchos países de la América. En él se recortó, individualizó, reguló y delimitó una práctica específica: la práctica pedagógica. Escritos casi siempre por curas párrocos, los planes de escuela -generalmente contenidos en un expediente- evidencian la compleja relación entre los poderes civiles y eclesiásticos en el establecimiento y la administración de la enseñanza de las primeras letras. Ahora bien, esta escuela de la que hablan los planes, no es la escuela parroquial, no es la escuela conventual, tampoco podemos asociarla a la enseñanza clandestina ni a la doméstica, mucho menos a la escuela doctrinal. Se trata de la escuela pública que emerge-lentamente por cierto- como forma tangible y real, disímil a otros espacios tanto públicos como privados, en particular, la iglesia, la casa, el taller y el hospicio.

En el momento en que aparecen las prácticas y los discursos que posibilitaron la irrupción de la escuela pública, varias voces empezaron a clamar por la separación de la instrucción de primeras letras de las demás actividades y escenarios de la vida ordinaria en donde eventualmente se realizara un acto de instrucción. Simón Rodríguez, por ejemplo, criticaba a los padres que fiaban la educación de sus hijos a cualquier vecino medianamente instruido, decía escuetamente: «basta para conocerlo fijar un poco de atención en las peluquerías y barberías que sirven de escuela; y sin detenerse en examinar su método, ni la habilidad de sus maestros, pásese a averiguar con qué autoridad se han establecido, quiénes son sus discípulos y qué procesos hacen» (Rodríguez, 1999, p. 204). Semejante crítica era a la vez una solicitud a favor del nombramiento de maestros públicos, regulados por el virreinato, para que se ocuparan de la enseñanza de los niños, al tiempo que se hacía necesario que hubiese un espacio propio para esta labor. 
Los planes hablaban de: cómo agrupar niños pobres, cómo hacer el contrato de aprendizaje, qué se les ponía a hacer, en qué lugar sentarse, a qué horas iban a misa, a qué horas descansaban, de qué fecha a qué fecha debían asistir a ese lugar, qué tenían que llevar, con cuanto se podía pagar lo que un sujeto misterioso hacía, cómo se debían ordenar, dónde se debían inscribir, ante quien se oponían esos sujetos públicos, qué preguntas se les hacían, para qué servía el título, las indicaciones de cómo tomar la pluma, etc. En ellos quedó atrapada, como en una red, una serie de nociones que fueron conformando aquellos objetos que convocaban la reflexión acerca de la enseñanza, y por lo tanto, aquellos primeros objetos del saber pedagógico.

\section{Tabla 1}

Expedientes y planes de escuela

\begin{tabular}{|c|c|c|c|c|}
\hline \# & Año y lugar & Nombre del documento & Interviniente & Ubicación \\
\hline 1 & $\begin{array}{l}1774 \\
\text { Santafé }\end{array}$ & $\begin{array}{l}\text { Método provisional e interino de los } \\
\text { estudios que han de observar los cole- } \\
\text { gios de Santa Fe, por ahora, y hasta tan- } \\
\text { to que se erige universidad pública o su } \\
\text { Majestad dispone otra cosa }\end{array}$ & $\begin{array}{l}\text { Francisco } \\
\text { Antonio } \\
\text { Moreno } \\
\text { y Escandón }\end{array}$ & $\begin{array}{l}\text { AGN, Archivo General } \\
\text { de la Nación: Anexo } \\
\text { Instrucción Pública, fo- } \\
\text { lios. 219-ss. }\end{array}$ \\
\hline 2 & $\begin{array}{l}1781 \\
\text { Popayán }\end{array}$ & $\begin{array}{l}\text { Fundación y establecimiento de la } \\
\text { Escuela de Christo que fue de la Com- } \\
\text { pañía }\end{array}$ & $\begin{array}{l}\text { Juan Mariano } \\
\text { de Grijalba }\end{array}$ & $\begin{array}{l}\text { AEP: Seminarios y Co- } \\
\text { legios. } 1780-1789 \text {. Car- } \\
\text { peta s. f. }\end{array}$ \\
\hline 3 & $\begin{array}{l}1782 \\
\text { Sogamoso }\end{array}$ & $\begin{array}{l}\text { El Corregidor y teniente del partido de } \\
\text { Sogamoso sobre la necesidad de que en } \\
\text { la parroquia cabeza de él se establezca } \\
\text { escuela de primeras letras, como la hay } \\
\text { en otras más civilizadas, y asigne sufi- } \\
\text { ciente dotación }\end{array}$ & $\begin{array}{l}\text { Juan de la Cruz } \\
\text { Gastelbondo }\end{array}$ & $\begin{array}{l}\text { AGN: Colegios. Tomo 4, } \\
\text { folios } 296 \mathrm{r} \text { a } 353 \mathrm{v}\end{array}$ \\
\hline 4 & $\begin{array}{l}1785 \\
\text { Lenguazaque }\end{array}$ & $\begin{array}{l}\text { Método que deben seguir los maestros } \\
\text { del pueblo de Lenguazaque formado por } \\
\text { su cura Don Josef Duquesne }\end{array}$ & $\begin{array}{l}\text { Domingo } \\
\text { Duquesne } \\
\text { de la Madrid }\end{array}$ & $\begin{array}{l}\text { AGN: Instrucción } \\
\text { Pública. Miscelánea. T. } \\
\text { 118, fol. 45-49, doc. } 12 .\end{array}$ \\
\hline 5 & $\begin{array}{l}1785 \\
\text { San Gil }\end{array}$ & $\begin{array}{l}\text { Autos sobre el establecimiento de escue- } \\
\text { la de primeras letras en la villa de Santa } \\
\text { Cruz y San Gil y fundación de cátedra de } \\
\text { gramática }\end{array}$ & $\begin{array}{l}\text { Josef Ignacio } \\
\text { Hortegat de la } \\
\text { Rocha }\end{array}$ & $\begin{array}{l}\text { AGN: Instrucción } \\
\text { Pública. Archivo Anexo. } \\
\text { Tomo 2, folios 302-374. }\end{array}$ \\
\hline 6 & $\begin{array}{l}1787 \\
\text { Turbaco }\end{array}$ & $\begin{array}{l}\text { Plan de Universidad y Estudios Genera- } \\
\text { les que se propone al Rey Nuestro Señor, } \\
\text { para establecerse, si es de su Soberano } \\
\text { Real agrado, en la ciudad de Santa Fe, } \\
\text { capital del Nuevo Reyno de Granada }\end{array}$ & $\begin{array}{l}\text { Antonio Caballero } \\
\text { y Góngora }\end{array}$ & $\begin{array}{l}\text { AGN: Instrucción } \\
\text { Pública. Tomo 2, folios } \\
\text { 198-218v. }\end{array}$ \\
\hline 7 & $\begin{array}{l}1789 \\
\text { Santafé }\end{array}$ & $\begin{array}{l}\text { Expediente sobre la fundación del } \\
\text { Convento y Colegio de la Enseñanza de } \\
\text { Bogotá }\end{array}$ & $\begin{array}{l}\text { María Clemencia } \\
\text { Caicedo }\end{array}$ & $\begin{array}{l}\text { ACE, Archivo Convento } \\
\text { de la Enseñanza: Libros } \\
1 \text { y 2. s. f. }\end{array}$ \\
\hline 8 & $\begin{array}{l}1789 \\
\text { Girón }\end{array}$ & $\begin{array}{l}\text { Plan de una escuela de primeras letras } \\
\text { para la ciudad de San Juan de Girón, } \\
\text { presentado por el Dr. Don Felipe Salgar }\end{array}$ & $\begin{array}{l}\text { Phelipe de } \\
\text { Salgar }\end{array}$ & $\begin{array}{l}\text { AGN: Fondo Colegios, } \\
\text { Tomo } 2,1^{\text {a }} \text { Parte, folios } \\
948-1018 .\end{array}$ \\
\hline 9 & $\begin{array}{l}1792 \\
\text { Ubaté }\end{array}$ & $\begin{array}{l}\text { Plan y método que se ha de observar en } \\
\text { la escuela, que según establecido por las } \\
\text { leyes, ordenado novissimamente por nue- } \\
\text { stros catholicos, monarcas y mandado } \\
\text { observar por la Real Audiencia, y supe- } \\
\text { rior Gobierno de este Reyno; se establece } \\
\text { en este pueblo de San Diego de Ubaté }\end{array}$ & $\begin{array}{l}\text { Fray Antonio } \\
\text { de Miranda }\end{array}$ & $\begin{array}{l}\text { AGN: Fondo Colegios. } \\
\text { Tomo 3, folios 821- } \\
\text { 827r. }\end{array}$ \\
\hline
\end{tabular}




\begin{tabular}{|c|c|c|c|c|}
\hline \# & Año y lugar & Nombre del documento & Interviniente & Ubicación \\
\hline 10 & $\begin{array}{l}1793 \\
\text { Popayán }\end{array}$ & $\begin{array}{l}\text { Fco José de Caldas, Padre general de } \\
\text { menores del Cabildo de Popayán, propo- } \\
\text { ne al Gobernador y comandante general } \\
\text { de la Provincia, se promueva el estudio } \\
\text { de artes y oficios, bajo la dirección de } \\
\text { maestros artesanos idóneos, para salvar } \\
\text { de la ociosidad y de la perdición a los } \\
\text { jóvenes nobles y plebeyos de la ciudad }\end{array}$ & $\begin{array}{l}\text { Francisco José } \\
\text { de Caldas }\end{array}$ & $\begin{array}{l}\text { Hernández, G. (1983) } \\
\text { Documentos para la } \\
\text { historia de la educación } \\
\text { en Colombia. Tomo V. } \\
\text { Bogotá: Editorial Nelly, } \\
\text { pp. 333-344. }\end{array}$ \\
\hline 11 & $\begin{array}{l}1794 \\
\text { Caracas }\end{array}$ & $\begin{array}{l}\text { Estado actual de la escuela y nuevo } \\
\text { establecimiento de ella }\end{array}$ & $\begin{array}{l}\text { Simón Narciso } \\
\text { Rodríguez }\end{array}$ & $\begin{array}{l}\text { AAC, Archivo del } \\
\text { Ayuntamiento Caracas: } \\
\text { Expediente } \mathrm{N}^{0} 19 .\end{array}$ \\
\hline 12 & $\begin{array}{l}1798 \\
\text { Maracaibo }\end{array}$ & $\begin{array}{l}\text { Instrucción práctica para el gobierno } \\
\text { económico de las escuelas de Maracai- } \\
\text { bo, con arreglo a las circunstancias del } \\
\text { lugar y demás que debe tenerse presente } \\
\text { para el mejor método y orden que debe } \\
\text { de observarse a fin de hacer más fácil la } \\
\text { enseñanza }\end{array}$ & $\begin{array}{l}\text { Andr } \\
\text { de } \mathrm{M}\end{array}$ & $\begin{array}{l}\text { AGI, Archivo Gene- } \\
\text { ral de Indias (Sevilla, } \\
\text { España): Audiencia de } \\
\text { Caracas. Legajo 148, } \\
\text { folios 653-714v. }\end{array}$ \\
\hline 13 & $\begin{array}{l}1800 \\
\text { Mompox }\end{array}$ & $\begin{array}{l}\text { Expedientes de la fundación de un ho- } \\
\text { spicio y hospital, escuela y colegio en las } \\
\text { villas de Mompox, por Don Pedro Mar- } \\
\text { tínez de Pinillos y su mujer }\end{array}$ & $\begin{array}{l}\text { Pedro Martínez } \\
\text { y Manuela T. } \\
\text { de Nájera }\end{array}$ & $\begin{array}{l}\text { AGI: Audiencia de San- } \\
\text { tafé, legajo } 1020 .\end{array}$ \\
\hline 14 & $\begin{array}{l}1801 \\
\text { Santafé }\end{array}$ & $\begin{array}{l}\text { Ordenanzas para la dirección y gobier- } \\
\text { no de la escuela que instituyó y fundó } \\
\text { en esta ciudad de Santa Fe Don Pedro } \\
\text { de Ugarte y doña Josefa Franqui su le- } \\
\text { gítima mujer, formados por sus sobrinos } \\
\text { y patrones Don Antonio y Don Nicolás } \\
\text { de Ugarte }\end{array}$ & onio & $\begin{array}{l}\text { BNC: Sala de Libros Ra- } \\
\text { ros y Curiosos. Protoco- } \\
\text { los. Instrucción Pública. } \\
\text { Folios } 347-352 v \text {. }\end{array}$ \\
\hline 15 & $\begin{array}{l}1804 \\
\text { Cartago }\end{array}$ & $\begin{array}{l}\text { El bachiller don Joseph Gregorio Vás- } \\
\text { quez de Piedrahita sobre la provisión de } \\
\text { la escuela de Cartago }\end{array}$ & $\begin{array}{l}\text { Joseph } \\
\text { Gregorio } \\
\text { Vásquez }\end{array}$ & $\begin{array}{l}\text { AGN: Colonia, Colegios. } \\
\text { Tomo 1, folios 656-839 }\end{array}$ \\
\hline 16 & $\begin{array}{l}1805 \\
\text { Caracas }\end{array}$ & $\begin{array}{l}\text { Expediente sobre la aprobación de una } \\
\text { escuela de primeras letras para la en- } \\
\text { señanza de los pardos en la ciudad de } \\
\text { Caracas }\end{array}$ & $\begin{array}{l}\text { Juan José } \\
\text { Mora, Felipe } \\
\text { Piña, et al. }\end{array}$ & $\begin{array}{l}\text { ACMC, Archivo del } \\
\text { Consejo Municipal de } \\
\text { Caracas: Expediente } \\
\text { sobre Escuelas. s. f. }\end{array}$ \\
\hline 17 & $\begin{array}{l}1805 \\
\text { Santafé }\end{array}$ & $\begin{array}{l}\text { El doctor don Nicolás Cuervo, sobre cre- } \\
\text { ación de escuelas en los barrios de esta } \\
\text { capital }\end{array}$ & Nicolás $\mathrm{Cu}$ & $\begin{array}{l}\text { BNC: Fondo Antiguo, } \\
\text { Instrucción Pública. Li- } \\
\text { bro 352, f. 388r-393r. }\end{array}$ \\
\hline 18 & $\begin{array}{l}1806 \\
\text { Arma } \\
\text { de Rionegro }\end{array}$ & $\begin{array}{l}\text { Expediente Arma de Rionegro: oposi- } \\
\text { ción de maestros a la escuela de prime- } \\
\text { ras letras }\end{array}$ & $\begin{array}{l}\text { Manuel Bravo } \\
\text { y José Miguel } \\
\text { Álvarez }\end{array}$ & $\begin{array}{l}\text { BNC: Fondo Antiguo. } \\
\text { Protocolo. Instrucción } \\
\text { Pública. Vol. 421r-445v. }\end{array}$ \\
\hline 19 & $\begin{array}{l}1806 \\
\text { Soatá }\end{array}$ & $\begin{array}{l}\text { Expediente sobre la solicitud de creación } \\
\text { de escuela de primeras letras en Soatá }\end{array}$ & Luis de Ovalle & $\begin{array}{l}\text { AGN: Colonia. Instruc- } \\
\text { ción Pública. Ar. Anexo. } \\
\text { t. 4, f. 308-359. }\end{array}$ \\
\hline 20 & $\begin{array}{l}1807 \\
\text { Lloró }\end{array}$ & $\begin{array}{l}\text { Expediente formado para el estableci- } \\
\text { miento de una escuela de primeras letras } \\
\text { en el pueblo de Lloró y el de Quibdó }\end{array}$ & $\begin{array}{l}\text { Antonio Vivas } \\
\text { y su esposa }\end{array}$ & $\begin{array}{l}\text { AGN: Anexo. Instruc- } \\
\text { ción Pública. T. 4, folios } \\
\text { 289-295. }\end{array}$ \\
\hline 21 & $\begin{array}{l}1807 \\
\text { Quibdó }\end{array}$ & $\begin{array}{l}\text { Expediente formado para el estableci- } \\
\text { miento de una escuela de primeras letras } \\
\text { en el pueblo de Quibdó capital de la pro- } \\
\text { vincia del Citará con el objeto benéfico } \\
\text { de conseguir la civilización de los indios } \\
\text { de su corregimiento }\end{array}$ & $\begin{array}{l}\text { Luís José de } \\
\text { Etayo y Luisa } \\
\text { Herrera }\end{array}$ & $\begin{array}{l}\text { AGN: Anexo Instruc- } \\
\text { ción Pública. T. 4, folios } \\
\text { 299-304v. }\end{array}$ \\
\hline
\end{tabular}

(Continua en la siguiente página) 


\begin{tabular}{|c|c|c|c|c|}
\hline \# & Año y lugar & Nombre del documento & Interviniente & Ubicación \\
\hline 22 & $\begin{array}{l}1808 \\
\text { Santafé }\end{array}$ & $\begin{array}{l}\text { Miguel Jerónimo Sierra y Quintano soli- } \\
\text { cita se le libre título de maestro para po- } \\
\text { der instruir a la juventud de esta capital }\end{array}$ & $\begin{array}{l}\text { Miguel } \\
\text { Jerónimo } \\
\text { Sierra }\end{array}$ & $\begin{array}{l}\text { AGN: Instrucción } \\
\text { Pública. Tomo 2, folios } \\
\text { 375-379. }\end{array}$ \\
\hline 23 & $\begin{array}{l}1808 \\
\text { Santafé }\end{array}$ & Plan de una Escuela Patriótica & $\begin{array}{l}\text { El Amigo de } \\
\text { los niños }\end{array}$ & $\begin{array}{l}\text { Semanario del Nuevo } \\
\text { Reino de Granada. No } \\
\text { 11-15, pp. 87-146. }\end{array}$ \\
\hline 24 & $\begin{array}{l}1809 \\
\text { Novita }\end{array}$ & $\begin{array}{l}\text { El Teniente Gobernador de Nóvita y } \\
\text { el Cura Vicario sobre establecimiento } \\
\text { de escuela y arbitrio para el sueldo del } \\
\text { maestro }\end{array}$ & $\begin{array}{l}\text { Narciso } \\
\text { Hurtado }\end{array}$ & $\begin{array}{l}\text { AGN: Colonia. Colegios. } \\
\text { Tomo 1, folios 61-63v. }\end{array}$ \\
\hline 25 & $\begin{array}{l}1809 \\
\text { Santafé }\end{array}$ & $\begin{array}{l}\text { Ordenanzas que han de regir la escuela, } \\
\text { que va a fundar en Las Nieves su actual } \\
\text { cura interino, Don Santiago de Torres }\end{array}$ & $\begin{array}{l}\text { Santiago de } \\
\text { Torres }\end{array}$ & $\begin{array}{l}\text { AGN: Instrucción } \\
\text { Pública. Anexo. Tomo } \\
\text { 4, folios 380-397v. }\end{array}$ \\
\hline 26 & $\begin{array}{l}1816 \\
\text { Coro }\end{array}$ & $\begin{array}{l}\text { Expediente sobre la formación de una } \\
\text { casa de estudios y escuela de primeras } \\
\text { letras en la ciudad de Coro (AEM, Archi- } \\
\text { vo Eclesiástico de Mérida) }\end{array}$ & $\begin{array}{l}\text { Narciso } \\
\text { de Cereceda }\end{array}$ & $\begin{array}{l}\text { Leal, I. (1968). Docu- } \\
\text { mentos para la historia } \\
\text { de la educación en Ve- } \\
\text { nezuela, pp. } 379-388 \text {. }\end{array}$ \\
\hline 27 & $\begin{array}{l}1818 \\
\text { Popayán }\end{array}$ & $\begin{array}{l}\text { Plan de enseñanza para la escuela de } \\
\text { primeras letras de esta Capital sujeta a } \\
\text { la dirección del Rector del Real Colegio } \\
\text { Seminario de San Francisco de Asís }\end{array}$ & $\begin{array}{l}\text { Andrés } \\
\text { Marcelino } \\
\text { Pérez } \\
\text { de Valencia }\end{array}$ & $\begin{array}{l}\text { AEP, Archivo Eclesiás- } \\
\text { tico de Popayán: Libro } \\
67, \text { s. f. }\end{array}$ \\
\hline 28 & $\begin{array}{l}1819 \\
\text { Medellín }\end{array}$ & $\begin{array}{l}\text { Reglamento para las escuelas de la pro- } \\
\text { vincia de Antioquia formado por orden } \\
\text { del Gobierno }\end{array}$ & $\begin{array}{l}\text { Manuel María } \\
\text { Viller Calderón }\end{array}$ & $\begin{array}{l}\text { B.N: Sala de Investi- } \\
\text { gadores. Sala } 2^{\text {a }} \text { No. } \\
12767, \text { pp. } 155^{-179} \text {. }\end{array}$ \\
\hline 29 & $\begin{array}{l}1820 \\
\text { Rionegro }\end{array}$ & $\begin{array}{l}\text { Decreto sobre establecimiento de escue- } \\
\text { las públicas en La Gran Colombia }\end{array}$ & $\begin{array}{l}\text { Estanislao } \\
\text { Vergara }\end{array}$ & $\begin{array}{l}\text { AHA, Archivo Histórico } \\
\text { de Antioquia, s. f. }\end{array}$ \\
\hline 30 & $\begin{array}{l}1821 \\
\text { Caracas }\end{array}$ & $\begin{array}{l}\text { Reglamento de las escuelas de educación } \\
\text { cristiana y civil de la ciudad de Caracas }\end{array}$ & $\begin{array}{l}\text { Ayuntamiento } \\
\text { de Caracas }\end{array}$ & $\begin{array}{l}\text { AGN (Venezuela): Actas } \\
\text { Ayuntamiento. Sesión } \\
\text { enero 11, f. 24. }\end{array}$ \\
\hline
\end{tabular}

Nota: Esta documentación hace parte del Archivo Pedagógico de la Colonia, y fue editado por Alberto Martínez Boom en el año 2011 con un estudio introductorio titulado: «El plan y la individualización de la forma escuela». Fuente: Memorias de la escuela pública. Expedientes y planes de escuela en Colombia y Venezuela, 1774-1821.

En los planes encontramos también escenas que ejemplifican las pedagogías pasivas, por ejemplo, la normativa del bachiller don Joseph Gregorio Vásquez de Piedrahita quien buscaba la provisión de la escuela de Cartago:

Los discípulos han de ver al maestro tomar la pluma y como la maneja, para que aprenda la verdadera colocación de los brazos sobre la mesa, el buen aire y gesto con que se debe escribir. La cabeza ha de estar medianamente inclinada, el pecho apartado de la mesa, la mano izquierda ha de sujetar el papel y volverle lo preciso, la esquina izquierda del papel que cae debajo de la mano que la sujeta ha de mirar a la mitad del pecho y la derecha ha de cuatro dedos más alta que la otra. El que le pone de otro modo va fuera del camino del verdadero arte (AGN, Colonia, Colegios, tomo I, f. 683).

Estas operaciones multiformes y fragmentarias repletas de detalle, desprovistas de ideología, formalizan una práctica que terminará constituyendo toda una manera de hacer y de vivir. En la misma dirección podemos observar concepciones de la época 
sobre lo que los propios personajes exponen que es la escuela. Don Manuel Bravo dirá en Arma de Río Negro cuando le preguntan por su definición de escuela: «es la junta y congregación de los niños que estén bajo la dirección de un maestro» ${ }^{13}$; don José Miguel Álvarez quien se presentaba ante el Cabildo para cumplir con el examen que le permitiría hacerse cargo de una escuela de primeras letras contestará ante la misma pregunta: «que es escuela el primer principio de la religión» ${ }^{14}$. Bien visto, entramos con ellos a otra constelación conceptual.

La afinidad de la escuela con otras prácticas de recogimiento y encierro le permitió adquirir una espacialidad inmanente. Aislar, preservar y proteger se fue asociando sutilmente a las funciones de la instrucción, lo que delimitaba la escuela como un espacio que mantiene de cierta manera alejada a los infantes de los vicios, los ruidos, las tentaciones o la corrupción. Tal era el pedido de Juan Luis Vives al afirmar que «lo más conveniente [era] establecer la escuela fuera de la ciudad, sobre todo si [esta era] marítima o habitada de comerciantes; no siendo tampoco a propósito el paraje donde [salieran] a pasear los ociosos, ni cerca de caminos frecuentados» (Vives, 1923, p. 40). De este modo, se fue perfilando un «adentro» que tras los muros infranqueables de la escuela, debía mantener a los infantes protegidos de los peligros del «afuera». El espacio sería claramente cercado pero no solo constituyéndose como un espacio físico sino también como un espacio social y diferenciado al interior de la escuela.

La paulatina configuración de sus límites permitió a su vez la aparición de unos sujetos identificados como sus habitantes naturales: el maestro y los alumnos. El lugar común destinado a la enseñanza de los infantes fue ganando en estabilidad así en principio no siempre se erigiera un lugar propiamente construido para este fin. De todas maneras, con edificio propio o no, la escuela -aún como mera denominación- disputó y ganó al resto de lugares la primacía de la enseñanza.

La ordenación interna de la escuela en un límite segmentado y acotado, en el que hay una coordinación cronométrica de las principales actividades, con cuerpos conscientemente ubicados en el espacio para ritualizar sus actividades, cada una de ellas regulada y vigilada permite considerar, siguiendo a Antonio Caballero y Góngora, «a los niños separados ya del seno y de la disciplina de sus padres» ${ }^{15}$. El niño ya no estaba en su cálido hogar sino en otro lugar que supone una separación, del mundo de los adultos como en una especie de "cuarentena», este largo periodo de reclusión de los niños, en cierto modo equiparable al encierro que empezaron experimentar los locos, los pobres y las prostitutas, se conoció como escolarización (Ariès, 1987, pp. 11-12), en otras palabras, la escuela es una etapa que se diferenció claramente de la casa.

Se produce, entonces, la definición de lo que en adelante fue considerada la primera edad, susceptible de intervención, modelaje y seguimiento, produciéndose también la segregación de los menores (minoridad) mediante los procedimientos de alojar a dichos sujetos en lugares ad hoc bajo el cuidado de ciertos sujetos (el cuerpo del enseñante), por varias horas al día, durante cierta porción del año. Espacio de encierro que en su propio límite produjo unas formas específicas de subjetividad: escolares, alumnos, cadetes, niños, decuriones, aprendices, empollones, discípulos, etc., hechos a la medida de cada modelo y de cada lugar.

13 BNC, Fondo Antiguo, Protocolo, Instrucción pública, Vol. 1, f. 441.

14 BNC, Fondo Antiguo, Protocolo, Instrucción pública, Vol. 1, f. 436v.

15 AGN, Instrucción pública, tomo 2, f. 206v. 
Felipe Salgar proponía en su plan que los infantes de todas la clases sociales debían acudir a la escuela a aprender los primeros rudimentos, sin embargo, es enfático en establecer que las diferencias de estirpe debían estar claramente trazadas en el aula de clase: «se hará en la sala más grande de la casa del maestro una división, que consistirá en separar los bancos o escaños de la testera superior de los de la inferior, dejando entre unos y otros una media vara de intermedio. Servirá esto para denotar que los niños nobles ocupan las bancas de arriba y los plebeyos y gentes de castas las de abajo» ${ }^{16}$. Los niños aprenderían desde su tierna edad que en el ordenamiento espacial -incluso el escolardebían conservarse las relaciones de poder, tal como sucedía con la distribución espacial al interior de la iglesia, pues los poderes de la ciudad estaban claramente diferenciados allí; al celebrarse los actos litúrgicos los neogranadinos prestantes se debían ubicar más cerca al atrio, mientras que los de castas inferiores debían ubicarse hacia a la salida de la iglesia. En el aula de clase, tanto los niños nobles como los plebeyos debían aprender que en el espacio cada uno debía tener un lugar diferenciado en el que ambas castas sabían cuál era la privilegiada.

Así lo señala el expediente sobre la aprobación de una escuela de primeras letras para la enseñanza de los pardos en Caracas:

[...] que dará reglas [al maestro] a la moderación y compostura con que los discípulos deben conducirse de sus casas a la escuela, y de este a aquella, y cada cuando salgan a la calle, corrigiendo con prudencia $y$ tesón lo que los haga entrar en no causar incomodidades a los vecinos con juegos y arrojamiento de piedras en la calle, con perjuicio de las fábricas, o edificios (Martínez-Boom, 2011, pp. 87-88).

Las fronteras de la escuela constituyeron también un lugar de encierro, aunque no hubiese barrotes, las paredes de las aulas no podían ser franqueadas. Encierro infantil que podemos asociar a la imagen conventual pero en dirección muy diferente, importaba formar en la vida tanto civil como cristiana bajo prácticas de policía a fin de formar vasallos obedientes, leales al soberano y útiles al reino tal y como lo dice el plan de escuela del padre Miranda:

[...] la educación de los primeros años es la piedra angular sobre que carga todo el peso de las obligaciones del hombre así es que debe precisamente dividirse en la doctrina que mira la religión y en poner aptos a los jóvenes para seguir el camino de la vida civil siendo útiles al Rey, a la patria, y a los conciudadanos (AGN, Colonia, Colegios, tomo 3, f. 823v-824r).

En los planes también se disponía la repartición del tiempo escolar. El tiempo determinaba en primera instancia una fracción general: «todos los vecinos que tengan algún hijo, que manifieste alguna habilidad desde dicho día lo mandarán a la escuela, desde las siete de la mañana hasta las once del día y por la tarde desde las dos hasta las cinco ${ }^{17}$. En lo específico determinaba también una rutina que debía seguir cada niño en el transcurso del día en la escuela, es decir, que se producía un régimen donde el maestro sabía lo que estaba haciendo su discípulo como lo expresa el plan de estudios generales de Caballero y Góngora:

16 AGN, Colonia, Colegios, tomo 2, f. 950r-950v.

17 AGN, Colonia, Colegios, tomo 3, f. 821r. 
[...] las lecciones diarias deben tenerse desde las siete y media de la mañana (en que ya los niños habrán oído misa y desayunado) hasta las once, y desde las dos y media hasta las cinco: dándoseles un rato de diversión según lo propuesto en el estudio general (AGN, Instrucción pública, tomo 2, f. 212).

No deja de sorprender constatar como las rutinas de los menores, abarcan tanto el interior como el afuera de la escuela: «antes de la seis se recogerán todos los niños en la escuela para ir en comunidad a oír misa de seis en la iglesia del colegio [...] a las once se irán a sus casas y cuidará el maestro que salgan con silencio y compostura [...] se enseñará también el andar a misa y les instruirá reglas de política y buena crianza ${ }^{18}$. Lo cotidiano se inventa en esos detalles de articulación espacio-temporales y se enuncian en el plan para reglamentar las prácticas como una acción constante, ininterrumpida, interesada en la minucia de la actividad y en la retícula de los movimientos más que en el resultado.

Además de la escuela aparece también el maestro al interior de un proceso precario, errático e indefinido. Esta figura, que surgió a grandes tumbos en medio de una multiplicidad de prácticas aparejadas a la enseñanza, fue en principio endeble y maleable ${ }^{19}$. Sus atributos y su posición en la jerarquía de los funcionarios y autoridades implicaron permanentes acomodos. Si bien los discursos filosóficos y políticos ponderan al maestro de escuela como un engranaje vital para la prosperidad de los pueblos, como el custodio de la moral y la civilidad, como el fiador del orden y la paz de la sociedad. En contraste, sus misivas constatan las miserias que soportaba en su vida cotidiana ${ }^{20}$, sus «urgencias lloradas» en la consecución de «un socorro de limosna».

Sin embargo, el cuerpo del enseñante público no es cualquier cuerpo, en él recaen requisitos y exigencias. En la regulación de la Congregación de San Casiano por la Corona en 1743, aparecen por ejemplo la certificación del Ordinario Eclesiástico sobre sus conocimientos en doctrina cristiana, la declaración juramentada de tres testigos sobre su vida, costumbres y limpieza de sangre (cristianos viejos, sin mezcla de mala sangre u otra secta), y la aprobación de los exámenes en el arte de leer, escribir y contar.

El interés de la Corona de formar un cuerpo enseñante secular que respondiera a las necesidades del Estado llevó a Carlos III a extinguir la Congregación en 1787 y erigir en su lugar el Colegio Académico del Noble Arte de las Primeras Letras, un instituto que aunque prácticamente desempeñaba el mismo rol de la extinta cofradía, supuso el primer intento de regular el trabajo del enseñante público para todo el reino. En la provisión sobre los estatutos del Colegio, el monarca aseveraba que el objeto de este establecimiento era:

18 AEP, Seminarios y Colegios. 1780-1789. Carpeta s.f.

19 En Crónica del desarraigo, describo uno de esos rostros emblemáticos de los primeros maestros públicos: Don Agustín Joseph de Torres (citado en Martínez-Boom et al, 1989, p. 126), y sus comunicaciones con la burocracia virreinal suplicando angustiosamente un «socorro de limosnas» como designaba su asignación anual.

20 Recordemos también al maestro Gastelbondo quien permaneció más de 15 años sin recibir salario alguno y sin embargo se mantuvo "sin faltar incesante al exercicio diario", o al maestro Ramírez quien después de dos años de trabajar en una escuela de Popayán no encontraba "razón ni motivo" para que se le retuviera su salario por ser «legítimamente ganado» con su «sudor y trabajo». 
[...] fomentar con trascendencia á todo el Reyno la perfecta educación de la juventud en los rudimentos de la Fé Católica, en las reglas del bien obrar, en el exercicio de las virtudes, y en el noble Arte de leer, escribir y contar; cultivando á los hombres desde su infancia y en los primeros pasos de su inteligencia, hasta que se proporcionen para hacer progresos en las virtudes, en las ciencias y en las artes, como que es la raiz fundamental de la conservación y aumento de la Religión, y el ramo mas interesante de la Policía y Gobierno económico del Estado (Carlos III, 1846, Libro octavo. De las ciencias, artes y oficios. Titulo primero. De las escuelas y maestros de primeras letras, y educación de niñas. Ley III).

Aunque autores como Juan Huarte de San Juan y Juan Luis Vives habían puntualizado desde el siglo XVI las características que debían tener aquellos que se dedicaran a la enseñanza, solo hasta mediados del siglo XVIII tal preocupación se convierte en regulación por parte de la autoridad pública. La investidura de la educación como objeto público ejerció profundas repercusiones sobre la figura que hasta ese momento había cumplido el rol de enseñante. La legislación, como expresión de las estrategias de poder estatal, determinó con suficiente énfasis que si la instrucción correspondía al terreno público, es decir, controlado por el Estado, ese mismo carácter debía recaer sobre todos aquellos que ejercieran el oficio de maestros. De esta forma se abrió paso la determinación de separar al funcionario religioso de cualquier actividad que implicara la enseñanza de la población civil, o por lo menos de diferenciar educación para eclesiásticos y educación para civiles.

$\mathrm{Al}$ énfasis colocado en el ejemplo magisterial Jovellanos agregará la importancia del método como tecnología regulatoria del oficio, de hecho definía al maestro como: «un buen cristiano con tal de que supiera el método», es decir, que si los métodos de enseñanza eran buenos se necesita saber muy poco para ejercer el oficio de enseñante, los maestros se encontraban en cualquier parte donde hubiera «un hombre sensato, honrado y que [tuviera] humanidad y patriotismo» (Jovellanos, 1962, p. 571). De aquí procede históricamente el estigma de que el maestro solo necesita poseer el método, en este caso, asignándole el papel esencialmente moral de ser el labriego de la virtud y la civilidad entre los hombres. Formar un cuerpo enseñante implicó constituir al maestro en un estabilizador social ${ }^{21}$.

En todo caso a finales del siglo XVIII, la relación del maestro con el saber que enseña adopta con el manual una forma de trabajo singular. Al respecto, la remisión al manual de Palomares en el plan de Caballero y Góngora en 1787, y más adelante a los manuales de Díaz Morante y Torcuato Torio -cuyos moldes para escribir se empiezan a reproducir en algunos planes, como el caso de la escuela de Cartago-, evidencian la irrupción en el interior del saber sobre la enseñanza de nuevos objetos de discurso, nuevos procedimientos, pero sobre todo la trasformación del estatuto del maestro, proceso que afecto casi todas las latitudes de los reinos de ultramar.

\section{A modo de cierre}

El análisis que se ha podido ofrecer acerca de la relación imperio-educación se circunscribe a un corpus documental de instituciones y prácticas que en la mayoría de los casos fueron motivados por intereses económicos y sociales en cuya materialidad se entrecruzan 
fuerzas locales, regionales y de ajuste centralista o imperial. El término «imperio» en el sentido en el que aquí se utiliza no implica una descripción exclusivamente política, hace referencia también a un predominio económico o cultural (Cipolla, Elliott et al., 1973, p. 14). He realizado este recorrido historiográfico y documental bajo la expectativa de describir y rastrear algunas de las condiciones de posibilidad que permitieron el surgimiento de la escuela pública y del modelo de escolarización asociado a ella que terminó por extenderse a todos los territorios de lo que hoy conocemos como América Latina además de generalizarse modos de educación definidos mediante la forma escuela.

En torno a estos procesos de expansión de lo escolar ¿es posible encontrar trabajos cotejables en distintas regiones del imperio español? Considero que sí y no solo por tratarse de un ejercicio de corte institucional sino por los enclaves que articulan documentos singulares con movimientos globales en torno a la evangelización, la irrupción de la escuela y la proliferación de sistemas de instrucción pública en toda la región de lo que hoy se nombra como América Latina.

En todo caso la reflexión sobre los modos como la escuela surge como acontecimiento político supone trazar ejercicios de educación comparada de las que podemos desprender consecuencias teóricas y metodológicas que afectan la manera como entendemos nuestra propia cultura.

Esta introducción de una idea de civilización, vinculada a prácticas de instrucción y buen gobierno adquirieron formas singulares y específicas que no corresponden con las condiciones de posibilidad de la escuela española y europea sino que pasaron por procesos de apropiación y adecuación que, para el caso del Nuevo Reino de Granada, y muy seguramente para el resto de colonias Hispanoamericanas, vincularon educación con vida en policía y conducción y gobierno de la pobreza.

\section{Referencias bibliográficas}

Altamira, R. (1924). La huella de España en América. Salamanca: Universidad de Salamanca.

Ariès, P. (1987). El niño y la vida familiar en el Antiguo Régimen. Madrid: Taurus.

Badura, B. (2013). Páginas de la historia del pueblo del Caney. Praga: Editorial Karolinum.

Bralich, J. (2014). Los arduos inicios de la escuela pública del Uruguay. En A. MartínezBoom y J. Bustamante (Comp.), Escuela pública y maestro en América Latina. Historias de un acontecimiento, siglos XVIII-XIX (pp. 237-257. ). Buenos Aires: Prometeo, UPN.

Brito, F. (1978). La estructura económica de Venezuela colonial. Caracas: UCV.

Bohórquez, L. E. (1956). La evolución educativa en Colombia. Bogotá: Cultural Colombiana.

Carmagnani, M. (1963). El salariado minero en Chile colonial: su desarrollo en una sociedad provincial: el Norte Chico, 169o-180o. Santiago: Universidad de Chile.

Cipolla, C. M., Elliott, J. H. et al. (1973). La decadencia económica de los imperios. Madrid: Alianza. 
Colmenares, G. (1978). Historia social, económica y cultural. En: Manual de Historia de Colombia, T. I. Bogotá: Instituto Colombiano de Cultura.

Colmenares, G. (1975). Cali: terratenientes, mineros y comerciantes. Siglo XVIII. Cali: U. Valle.

Daviols, J. P. (2001). Percepción e imágenes del mundo americano a través de los primeros testimonios. En F. Pease (dir.), El primer contacto y la formación de las nuevas sociedades. Historia General de América Latina, vol. 2 (pp. 487-504). Madrid: Unesco y Trotta.

Fisher, L. E. (1966). The last Inca Revolt, 1780-1783. Oklahoma: University of Oklahoma Press.

Foucault, M. (2006). Seguridad, territorio, población. México: Fondo de Cultura Económica.

Friede, J. (1963). Problemas sociales de los Aruacos. Bogotá: Universidad Nacional de Colombia.

Friede, J. (1968). Ordenanzas de Tunja (1575-1576). Boletín Cultural y Bibliográfico, 11(8), 140-162.

Friede, J. (Comp.) (1955). Documentos inéditos para la historia de Colombia: coleccionados en el Archivo General de Indias de Sevilla. Bogotá: Academia Colombiana de Historia.

García-Gallo, A. (1987). Los orígenes españoles de las instituciones americanas: Estudios de derecho indiano. Madrid: Real Academia de Jurisprudencia y Legislación.

Gibson, C. (1964). Los aztecas bajo el dominio español, 1519-1810. México: FCE.

Góngora, M. (1998). Estudios sobre la historia colonial de Hispanoamérica. Santiago: Editorial Universitaria.

Gonzalbo, P. (2001). Blancos, pobre y libertos. Los colores de la pobreza en el Virreinato de Nueva España. En A. Castillero Calvo (Dir.), Historia general de América Latina, vol. III, t. 2 (pp. 429-442). París: Unesco/Trotta.

Gonzalbo, P. (1985). La educación de la mujer en la Nueva España. México: SEP.

González, M. (1979). El resguardo en el Nuevo Reino de Granada. Bogotá: La Carreta.

Hunter, I. (1998). Repensar la escuela. Subjetividad, democracia y crítica. Barcelona: Pomares Corredor.

Jaramillo, J. (1968). Ensayos sobre historia social colombiana. Bogotá: Universidad Nacional.

Jovellanos, G. M. (1858). Bases para la formación de un plan general de instrucción pública. En Obras publicadas é inéditas de D. Gaspar Melchor de Jovellanos, vol. 1 (pp. 268-276 ). Madrid: M. Rivadeneyra.

Jovellanos, G. M. (1962). Memoria sobre educación pública. Madrid: Publicaciones Españolas. 
Konetzke, R. (1982). América Latina. La época colonial. México: Siglo XXI.

Krebs, R. (1992). La monarquía absoluta en Europa. El desarrollo del Estado moderno en los Siglos XVI, XVII y XVIII. Santiago: Editorial Universitaria.

Lee, A. (1964). Gonzalo Bermúdez primer catedrático de la lengua general de los Chibchas. Boletín de Historia y Antigüedades, 51(594-597).

Liévano, I. (1973). Los grandes conflictos sociales y económicos de nuestro siglo. Bogotá: Tercer Mundo.

Lohmann, G. (1947). Los americanos en las órdenes nobiliarias, 1529-190o. Madrid: Consejo Superior de Investigaciones Científicas.

Lucena, M. (1962). Las lenguas aborígenes neogranadinas entre 1602 y 1606. Boletín Cultural y Bibliográfico, 5(12), 1556-1560.

Lynch, J. (1976). Las revoluciones hispanoamericanas, 1808-1826. Barcelona: Ariel.

Manzano, J. (1950). Historia de las Recopilaciones de Indias: Siglo XVI. Madrid: Cultura Hispánica.

Martínez-Boom, A. (2011). Memorias de la Escuela Pública. Expedientes y planes de escuela en Colombia y Venezuela, 1774-1821. Bucaramanga: UIS.

Martínez-Boom, A., Castro, J. O. y Noguera, C. E. (1989). Crónica del desarraigo: Historia del maestro en Colombia. Bogotá: Magisterio.

Martínez-Boom, A. (1982). De la evangelización a la instrucción pública. Contribución al estudio de las prácticas educativas coloniales. Bogotá: Universidad Pedagógica Nacional.

Mesa, C. E. (1973). La enseñanza del catecismo en el Nuevo Reino de Granada. Missionalia Hispánica, 30(90), 299-334.

Mesarza, A. (1955). Ordenanzas para la enseñanza de la religión. Boletín de Historia y Antigüedades, 212, 69-74.

Miranda, J. (1952). El tributo indígena en la Nueva España en el siglo XVI. México: El Colegio de México.

Mörner, M. (1979). La reorganización imperial de Hispanoamérica, 1760-1810. Cuadernos de Historia, 2. Tunja: Ediciones Nuestra América, UPTC.

Ots-Capdequi, J. M. (1965). El Estado español en las indias. México: Fondo de Cultura Económica.

Pacheco, J. M. Ecclesiástica Xaveriana (vol. VIII-IX).

Pacheco, J. M. (1964). La evangelización del Nuevo Reino. Siglo XVI. Historia Eclesiástica. Tomo 1. Colección Historia Extensa de Colombia, vol. XIII. Bogotá: Lerner.

Pietschmann, H. (2001). El ejercicio y los conflictos del poder en Hispanoamérica. En A. Castillero Calvo (Dir.), Historia general de América Latina, vol. III, t. 2 (pp. 669692). París: Unesco/Trotta. 
Querrien, A. (1994). Trabajos elementales sobre la escuela primaria. Madrid: Ediciones la Piqueta.

Restrepo, E. (2011). El Hospital San Juan de Dios 1635-1895. Una historia de la enfermedad, pobreza y muerte en Bogotá. Bogotá: Universidad Nacional de Colombia, CES.

Restrepo, E. (2010). El primer catecismo en lengua mosca. Santafé, 1605. Revista Colombiana de Educación, 59, 71-81.

Restrepo, E. (1997). Enfermedades y medicinas. Tres conceptos terapéuticos en el Nuevo Reino de Granada, 1550-1680. En H. Sotomayor et al. El medicamento en la historia de Colombia (pp. 55-81). Bogotá: Schering-Plough y Editorial Nomos.

Rodríguez, S. (1999). Obras completas (Tomo I). Caracas: Presidencia de la República.

Roldán, E. (2014). Instrucción pública, educación pública y escuela pública: tres conceptos claves en el origen de la nación mexicana, 1870-1833. En A. MartínezBoom y J. Bustamante (Comp.). Escuela pública y maestro en América Latina. Historias de un acontecimiento, siglos XVIII-XIX (pp. 61-91). Buenos Aires: Prometeo, Universidad Pedagógica Nacional.

Romero, M. G. (1960). Fr. Juan de los Barrios y la evangelización del Nuevo Reino de Granada. Bogotá: Ediciones ABC.

Rubio, J. I. (1983). El virreinato: Obras públicas y educación universitaria. México: F.C.E.

Ruiz, E. (1916). La magistratura indiana. Buenos Aires: Universidad Nacional de Buenos Aires.

Sarrailh, J. (1957). La España ilustrada de la segunda mitad del Siglo XVIII. México: Fondo de Cultura Económica.

Sanctis, D. de (1962). Breve y muy sumaria instrucción de utilidad para enseñar los nuevos en la fe, de lo que creer y obrar y de que se han de apartar para ser buenos cristianos. Boletín Cultural y Bibliográfico, 5(12).

Solorzano, J. (1776). Política indiana (Vol. 1). Madrid: Francisco Ramiro de Valenzuela.

Staples, A. (2005). Recuento de una batalla inconclusa: la educación mexicana de Iturbide a Juárez. México: El Colegio de México.

Tanck, D. (1999). Pueblos de indios y educación en el México colonial, 1750-1821. México: El Colegio de México.

Vespucci, A. (1951). El Nuevo Mundo. Cartas relativas a sus viajes y descubrimientos. Buenos Aires: Nova.

Villalobos, S. (1965). Comercio y contrabando en el Río de la Plata y Chile, 1700-1811. Buenos Aires: Eudeba. 
Ward, B. Proyecto económico en que se proponen varias providencias dirigidas a promover los intereses de España, con los medios y fondos necesarios para su planificación. Madrid: Joaquín Ibarra.

West, R. C. (1972). La minería de aluvión en Colombia durante el periodo colonial. Bogotá: Imprente Nacional.

Zamora, A. (1701). Historia de la Provincia de San Antonino, del Nuevo Reino de Granada. Barcelona: Imprenta de Joseph Llopis.

Zavala, S. (1972). La filosofía política en la conquista de América. México: Fondo de Cultura Económica.

\section{Siglas empleadas en el texto}

AAC Archivo del Ayuntamiento de Caracas.

ACE Archivo del Convento de la Enseñanza, Bogotá.

ACMC Archivo del Consejo Municipal de Caracas.

AEP Archivo Eclesiástico de Popayán.

AGI Archivo General de Indias, Sevilla.

AGN Archivo General de la Nación, Bogotá.

AHA Archivo Histórico de Antioquia, Medellín.

AHNB Archivo Histórico Nacional de Bogotá.

BNC Biblioteca Nacional de Colombia, Bogotá.

CP Colección de Provindencias tomadas sobre el extrañamiento. 